\title{
A Model for Mandatory Use of Software Technologies: An Integrative Approach by Applying Multiple Levels of Abstraction of Informing Science
}

\author{
Chang E. Koh, Victor R. Prybutok, Sherry D. Ryan, \\ and $Y u$ "Andy" Wu \\ University of North Texas, Denton, TX, USA \\ chang.koh@unt.edu; victor.prytutok@unt.edu; \\ sherry.ryan@unt.edu; andy.wu@unt.edu
}

\begin{abstract}
Taking the informing science perspective that construes systems at three levels of abstraction, we integrated findings from prior studies into a model for system use in mandatory environments. Data collected from 333 municipal government employees using mandatory systems were used to test the model. We found that captive users' attitudes toward system use plays a pivotal role while intention to use, the central construct in the Technology Acceptance Model (TAM), loses much of its explanatory power in mandatory settings. Both attitude and intention are not good predictors of use. Data analysis also supported our hypotheses about information quality, a system characteristic important to the first-level informing instance, and net benefits from system use, which are the main objectives of informing at the second level of abstraction. We discuss the implications of our findings for system design, the fundamental activity at the third level of abstraction.
\end{abstract}

Keywords: Mandatory software, user attitude, user satisfaction, information quality, system success, intention to use

\section{Introduction}

With the increasing integration of information technologies (IT) into business, today's organizations tend to sanction the use of information systems applications over which their employees do not have the privilege of selection. For example, applications such as enterprise resource planning (ERP) systems are widely used and standardize the way software technologies are applied to business processes. Alternatively, an organization may install a standard array of desktop applications, each befitting certain tasks. To study system use in such mandatory environments, researchers often apply the Technology Acceptance Model (TAM) with two approaches: (a) using the TAM as is but adding voluntariness

Material published as part of this publication, either on-line or in print, is copyrighted by the Informing Science Institute. Permission to make digital or paper copy of part or all of these works for personal or classroom use is granted without fee provided that the copies are not made or distributed for profit or commercial advantage AND that copies 1) bear this notice in full and 2) give the full citation on the first page. It is permissible to abstract these works so long as credit is given. To copy in all other cases or to republish or to post on a server or to redistribute to lists requires specific permission and payment of a fee. Contact 0HPublisher@InformingScience.org to request redistribution permission. as a moderator, or (b) adding antecedents to perceived usefulness and perceived ease of use. Either way, the constructs of intention to use and use are central to the models, as they are in the TAM. We argue that both approaches are incognizant of the fact that, in mandatory environments, intention and use may not have enough variances to be meaningful criterion variables. 
Informing science considers systems at three levels of abstraction (E. Cohen, 1999; Gill \& Bhattacherjee, 2007, 2009). From this perspective, the centrality on intention and use reflects a limiting view that construes mandatory use only at the first level, i.e., the user is informed via system use. Mandatory systems, however, often aim at goals achieved only when new instances of informing occur. For instance, governments are taking advantage of the ever-increasing capabilities of IT to make their citizenry better informed. However, employees' mandated use of IT systems is no guarantee that benefits made possible by IT are indeed realized. To inform the citizens, first the employees must be properly informed and be able to trust information output from the systems. Second, a new instance of informing takes place when employees use the information to inform citizens. The desired results are benefits to the governments, such as better relationships with their constituencies, cost effectiveness, and positive image of the governments.

The purpose of this paper, therefore, is to develop a theoretical model to explain mandatory use of software technologies by employing multiple levels of abstraction in the spirit of informing science. Such a vantage point affords us an integrative view on prior studies. We adapted Wixom and Todd's (2005) model to explain a conceptual gap between system characteristics (specifically, information quality) and system use, which DeLone and McLean's (1992, 2003) milestone models of system success have not addressed in full. Wixom and Todd (2005) filled the gap by reasoning that users' evaluation of system characteristics ("object-based beliefs") impacts their affective feeling toward those characteristics ("object-based attitudes"), which, in turn, exerts influence on two TAM predictors of use - perceived usefulness and perceived ease of use ("behavioral beliefs"). Although Wixom and Todd (2005) did justice to user attitude toward system use ("behavioral attitude"), their model was not specifically designed for mandatory environments and thus treats intention as the ultimate criterion variable. We addressed this by introducing DeLone and McLean's (2003) constructs of user satisfaction and net benefits. The latter is the goal of informing at the second level of abstraction and the former is the connection between the first and second levels. Looking again at government systems, employees who are satisfied processors of information are the key to the successful creation of new instances of informing.

This paper is organized as follows. First, we briefly review the informing science framework and the three levels of abstraction, which are the foundation of our theoretical approach. Then, we propose our model and introduce the relevant theories and models that we integrate by using the informing science approach. We discuss why and how particular aspects of them are important to our model and present our hypotheses regarding the relationships between the constructs. Next, we describe how we collect data from users of mandated systems at a municipal government. This is followed by the results of data analysis. We then discuss our findings, especially the pivotal role played by attitude instead of intention. We conclude the paper after discussing its research and practical implications.

\section{Theoretical Background}

The aim of this paper is to build an exploratory model of mandatory use of software applications, following an approach in the spirit of informing science. E. Cohen (2009) defines the goal of informing science as to inform the clients with proper information so that their effectiveness is maximized. The informing environment is a complex one that can be viewed at three levels of abstraction - (a) the instance of being informed by an existing system; (b) the creation of new instances of informing; and (c) the creation of new designs for informing (E. Cohen, 1999; Gill \& Bhattacherjee, 2007, 2009). Taking this perspective, we can see that many organizational users are involved at least in the first two levels. They are informed by the output from the system (first level) and, in turn, use the information to generate more information for the organization's clientele (second level). For government employees, this is particularly so because the goal usually is to serve the government's constituency with information. At the first level, the employees are the 
client who is informed by the system; at the second, they are the informer who informs the external client, i.e., the citizenry that the government serves.

The ultimate goal of information systems is to enhance the effectiveness of the informed. Thus, a task completion system is an integral part of the informing science framework (E. Cohen, 1999; Gill \& Bhattacherjee, 2007). For organizational information systems, that translates into impact on the organization. DeLone and McLean $(1992,2003)$ summarized a plethora of studies on system success and proposed net benefits as the ultimate goal. For governments, information systems should generate the benefits of a better relationship with the constituency, more cost-effective ways to inform the citizenry, etc.

An information system is composed by interrelated task, technology, structure, and people (Gill \& Bhattacherjee, 2007). Therefore, while technology sits at the central position (E. Cohen, 1999), study of the informing science framework also calls for research on the "[b]iological and psychological issues in how clients attend, perceive, and act on information provided" and "[t]he decision-making environment itself, including its sociology and politics" (E. Cohen, 2009, p. 6). Important psychological factors that influence the use of software applications have been the focus of the Technology Adoption Model (TAM) and related research. However, most of the TAM studies examine users' voluntary adoption of applications, whereas many organizational systems are implemented in a mandatory environment. To date, studies of software use in such environments are still scarce. Our model (Figure 1), therefore, aims to address mandatory use of software, from how well the users perceive that they are informed (information quality) all the way to the organizational benefits realized from use of software. For the consideration of parsimony, the current study focuses on information quality, since low-quality information can cause misinterpretation of information, with serious organizational and social consequences (E. Cohen, 2000).

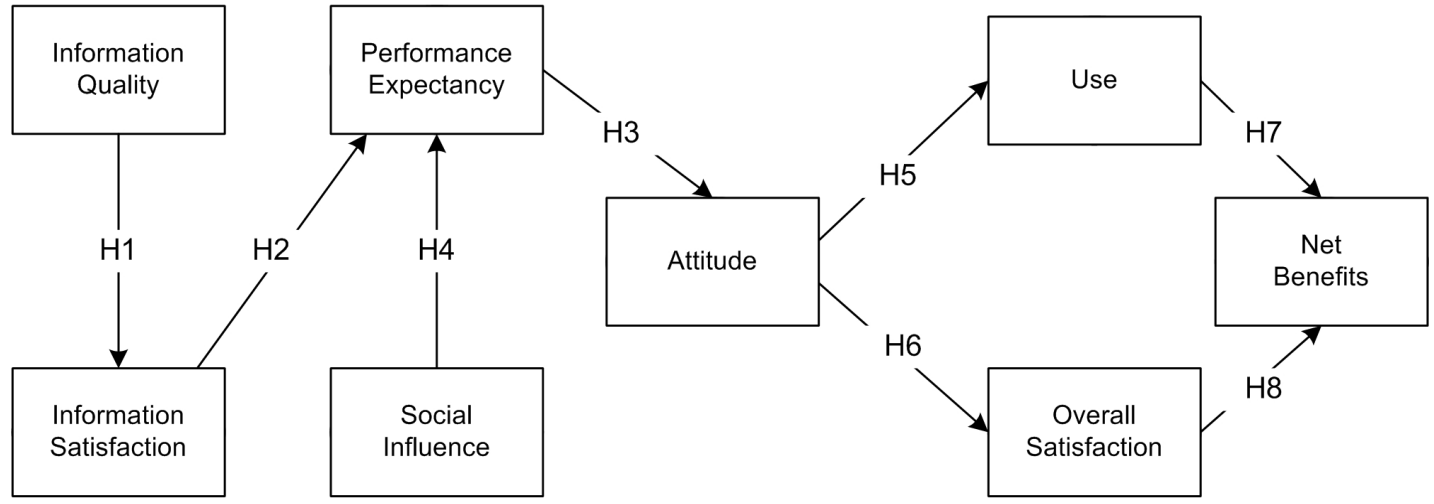

Figure 1. Model for Mandatory Use of Software Technologies (MMUST)

As we will describe in upcoming sections, DeLone and McLean's (1992, 2003) information systems (IS) success models left a gap between information quality and system use. Wixom and Todd (2005) filled the gap but did not consider anything beyond the intention to use systems. Their model, however, testified to the explanatory power of the TAM even when beliefs toward system objects are included in the picture.

The epicenter of TAM studies, however, is the intention construct, which is irrelevant in mandatory environments because users must use, not merely intend to use, a system. Nevertheless, researchers on mandatory use still cannot shake the habit of including intention in their models, while rarely considering organizational benefits. In a sense, these various research streams resemble the disciplinary "laser research" (E. Cohen, 2009), providing more depth than breadth. We, therefore, take a "lantern research" approach to study mandatory use of software, with the 
hope of "enlightening interrelationships of nearby objects" (E. Cohen, 2009, p. 2), the objects in this case being the pertinent constructs studied in the various research streams.

\section{DeLone and McLean Models on System Success}

Like E. Cohen's $(1999,2009)$ informing science framework, DeLone and McLean's $(1992,2003)$ IS success models drew upon Shannon and Weaver's (1949) theory on the communication process. Synthesizing an enormous array of studies on system success, DeLone and McLean (1992) organized the various dimensions of success proposed by researchers into six categories - system quality, information quality, use, user satisfaction, individual impact, and organizational impact. This taxonomy had its roots in Shannon and Weaver's (1949) view on three levels of information. DeLone and McLean (1992) further posited that as information follows through the stages of its consumption, system use correspondingly manifests its impacts at various output levels. Along a temporal axis, a system first demonstrates various degrees of system and information quality. Next, during their use of the system, users become satisfied or dissatisfied with its information products. Their use of the system then brings about impacts on the users' work, which then collectively lead to organizational impacts. In their ten year update of the model, DeLone and McLean (2003) proposed the use of a single "net benefits" construct, instead of the separate impacts at the individual and organizational levels, as the ultimate criterion of system success (see Figure 2).

Another notable modification in the updated model was the introduction of "intention to use" into the model as an alternative to use. DeLone and McLean (2003), however, were rather brief and ambiguous in their justification of such an introduction. They simply suggested that "intention to use' may be a worthwhile alternative measure in some contexts" (DeLone \& McLean, 2003, p. 23). In contrast, when presenting their original model, DeLone and McLean (1992) explicitly pointed out that "actual use, as a measure of I/S success, only makes sense for voluntary or discretionary users as opposed to captive users" (DeLone \& McLean, 1992, p. 66). It appears that their introduction of intention was no more than an acknowledgment of the massive influences of the TAM, at the center of which sits the construct of intention to use. Moreover, in both renditions of their model, DeLone and McLean $(1992,2003)$ did not provide a detailed account of how system quality and information quality are related to system use. This gap was filled by Wixom and Todd (2005), by connecting the quality constructs and other constructs from the TAM. Their model also drew heavily on the TAM. Therefore, before we introduce Wixom and Todd's (2005) model, in the next section we first provide a brief overview of the TAM.

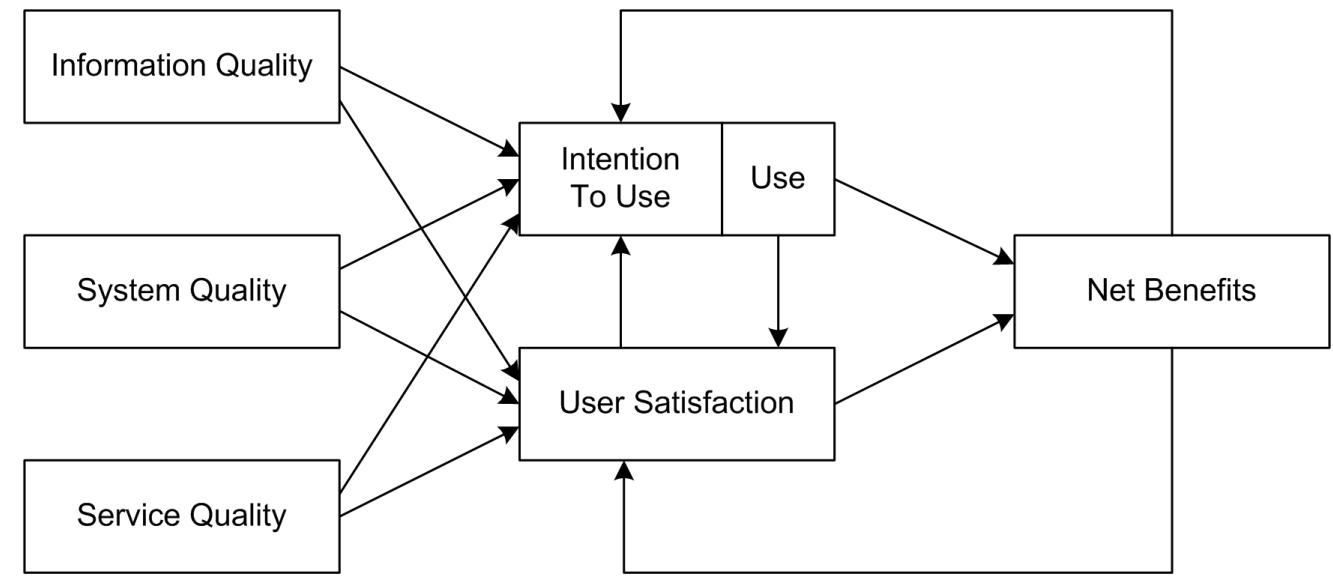

Figure 2. DeLone \& McLean's (2003) Updated IS Success Model 
Koh, Prybutok, Ryan, \& Wu

\section{Technology Adoption}

Ever since its birth in the late 1980s, the TAM (Davis, 1989; Davis, Bagozzi, \& Warshaw, 1989) has enjoyed extensive application and testing (Nah, Tan, \& Teh, 2004; Venkatesh \& Davis, 2000). A recent meta-analysis of TAM-related studies (Yousafzai, Foxall, \& Pallister, 2007a, 2007b) turned up 145 TAM-based articles published in 57 journals.

The TAM has its roots in the Theory of Reasoned Action (TRA) and there have been numerous variations on the TAM over the years. The TAM offers insight into how behavioral intention is formed. In its original form, the TAM posits that attitude toward use of a system is determined by two behavioral beliefs - perceived usefulness and perceived ease of use (see Figure 3). Perceived usefulness is "the degree to which a person believes that using a particular system would enhance his or her job performance" (Davis, 1989, p. 320). Perceived ease of use is "the degree to which a person believes that using a particular system would be free of effort" (Davis, 1989, p. 320). Both influence the user's attitude, which, in turn, influences user intention to adopt the application (Schepers \& Wetzels, 2007). Moreover, intention has been found to be a stable and strong predictor of system use (Taylor \& Todd, 1995).

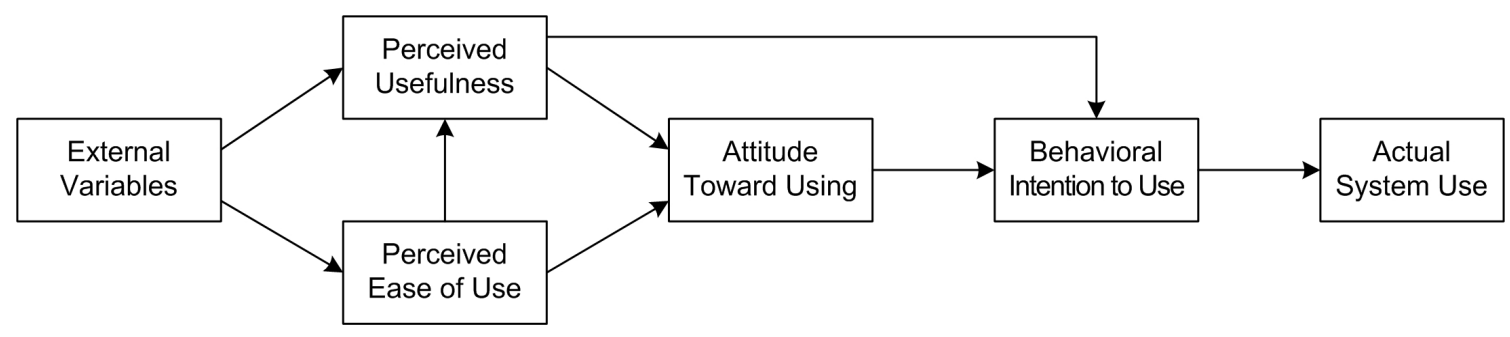

Figure 3. Technology Acceptance Model (Davis, 1989)

Since its inception, Davis' seminal work on the TAM (Davis, 1989; Davis et al., 1989) has spawned a remarkably large stream of related research. Venkatesh, Morris, Davis, and Davis (2003) identified and analyzed eight models that were closely related to the TAM and integrated them into a single model called the Unified Theory of Acceptance and Use of Technology (UTAUT). To indicate that the constructs used in the UTAUT were the result of synthesizing various related models, Venkatesh et al. (2003) replaced the label of "perceived usefulness" with "performance expectancy," and "perceived ease of use" with "effort expectancy," although the underlying definition of the constructs remained essentially the same. We prefer the UTAUT labels because of their independence of any particular TAM version or related model.

A major drawback of the TAM is that it does not provide an in-depth explanation about how the two beliefs (perceived usefulness and perceived ease of use) are formed or how they can be managed to alter user behaviors (Jensen \& Aanestad, 2007; Yousafzai et al., 2007a). Numerous studies were done to extend the TAM in terms of adding antecedents and moderating variables. Most notably, Venkatesh and Davis (2000) proposed the TAM2, which identified the antecedents to perceived usefulness, such as subjective norm, image, job relevance, output quality, and result demonstrability. A similar study (Venkatesh, 2000) identified another set of antecedents to perceived ease of use.

More recently, Venkatesh and Bala (2008) integrated these two studies into the TAM3. They also suggested a number of interventions that may be implemented to influence the determinants of perceived usefulness and ease of use. Additional research has also combined the TAM with other theoretical models and shifted the focus from initial adoption to incorporating multiple stages of continued use, e.g., the Technology Continuance Theory (Liao, Palvia, \& Chen, 2009). 


\section{Wixom and Todd Model}

Also detecting the conceptual gap between system/information quality and system use in the literature, Wixom and Todd (2005) suggested that the missing link could be found in the TAM (see Figure 4).

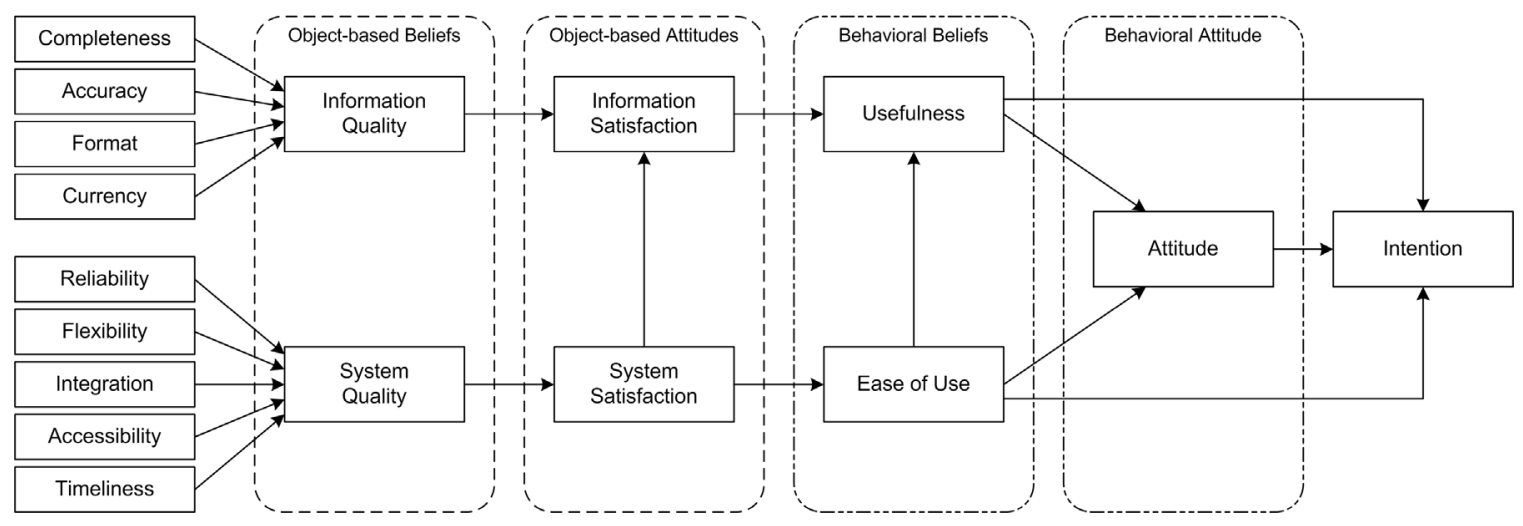

Figure 4. Integrated Research Model (Wixom \& Todd, 2005)

Wixom and Todd (2005) categorized all pertinent psychological constructs into object-based and behavioral types. Within either category there are beliefs and attitudes. Constructs that are related to system and information are object-based. Thus, system quality and information quality are object-based beliefs. Each of them respectively is related to system satisfaction or information satisfaction, which are object-based attitudes. The critical linkage in the entire picture is the relationships between object-based attitudes and behavioral beliefs, which are perceived usefulness and perceived ease-of-use in the TAM. As posited by the TAM, they influence users' behavioral attitude and, eventually, intention to use the system. In Wixom and Todd's (2005) view, object-based attitudes are poor direct predictors of use-related attitude and intention. However, through the mediation of behavioral beliefs (usefulness and ease of use), they do exert significant influence on behavioral attitudes, if they are consistent in time, target, and context with the behavior, i.e., adhering to Fishbein and Ajzen's (1975) “correspondence principle."

In terms of information quality, this object-based belief is the user's perception of the quality of the information included in the system (Wixom \& Todd, 2005). The attitude behavior literature purports that beliefs about objects are linked to attitude toward the object (Ajzen \& Fishbein, 1980). Everything else held constant, a commonsensical user will be satisfied with a piece of information if it is of good quality. This increases the user's confidence in using the information for carrying out tasks on hand. In other words, a user satisfied with the quality of the information he or she receives from the system is more likely to perceive that the information will enhance his or her work performance (Wixom \& Todd, 2005). Therefore, we hypothesize that:

H1: Higher information quality is related to higher level of satisfaction with the information.

H2: Higher level of satisfaction with information is related to higher level of performance expectancy.

Although Wixom and Todd (2005) illustrated a gap between system/information quality and use and IT value, their model did not complete the bridging work; rather, it stopped at intention. Neither use nor benefits from system use were covered. In addition, their model was tested only with volitional users and no test was done on the model's validity, or lack thereof, in a mandatory environment. We posit that in such an environment, attitude rather than intention should be the piv- 
Koh, Prybutok, Ryan, \& Wu

otal variable. In the next section, we discuss the past efforts at extending TAM to mandatory environments.

\section{Mandatory Use}

In a mandatory use environment, "users are required to use a specific technology or system in order to keep and perform their jobs" (Brown, Massey, Montoya-Weiss, \& Burkman, 2002, p. 283, emphasis original). The user must use the system, regardless of whether he or she intends to use it. This is in stark contrast to the volitional usage behavior studied by most TAM research. Mandatory use was considered a probable cause for mixed findings in TAM studies (Hartwick \& Barki, 1994; Mathieson, 1991; Taylor \& Todd, 1995; Venkatesh \& Davis, 2000). There have been efforts to modify the TAM to address mandatory use of software. However, to date they are still few and far between. Moreover, our observation is that intention to use has been so vested as the central construct in the model that researchers have a strong tendency to use it in their models for mandatory use. The paradox here is that, if a user is required to use a system, their intention to use is not likely to be relevant (Brown et al., 2002).

There are basically two approaches to using the TAM to examine mandatory use (Nah et al., 2004). First, some researchers used the same model to study both mandatory and volitional systems (e.g., Brown et al., 2002; Venkatesh \& Davis, 2000; Venkatesh et al., 2003). A typical modeling adjustment undertaken was to model voluntariness as a moderator of the relationship between intention and determinants of intention (e.g., Venkatesh et al., 2003). This was the approach used by the TAM2 (Venkatesh \& Davis, 2000) and TAM3 (Venkatesh \& Bala, 2008). In Venkatesh et al.'s (2003) UTAUT study, voluntariness was only found to have significant moderation effect when it interacted with three or four other moderators simultaneously. This, however, added complexity in interpreting the moderation effect and the exact role voluntariness played in the model. Parsimony of the model suffered as well.

Second, other researchers call for the reprise of the attitude construct that was in the earlier versions of the TAM but has disappeared during the evolution of the model. Attitude is an "individual's positive or negative feelings (evaluative effect) about performing the target behavior" (Fishbein \& Ajzen, 1975, p. 216). In the original TAM, attitude toward using the system (the "target behavior") was modeled to predict behavior directly (Davis, 1989) and to mediate the influence of perceived usefulness and perceived ease-of-use. Over time, intention was introduced and studies conducted in volitional environments showed that the explanatory power of the model was equally good with attitude removed (Brown et al., 2002; Nah et al., 2004). For the sake of parsimony, attitude was removed in later versions of the TAM, including the Parsimonious TAM, UTAUT, TAM2, and TAM3. As researchers broadened the contexts of system use in TAM studies, the importance of attitude resurfaced. For example, the TCT applied the TAM to explain the intention for continuation as opposed to initial adoption of a system. Attitude was found to be a significant predictor of continuance intention (Liao et al., 2009). As for mandatory use, arguments have been advanced that the removal of attitude causes an inaccurate representation of the phenomenon (Brown et al., 2002; Nah et al., 2004; Yousafzai et al., 2007b). Since captive users must use the system regardless of their intention, the linkage between intention and use and that between attitude and intention are broken (Brown et al., 2002; Nah et al., 2004; Yousafzai et al., $2007 \mathrm{~b}$ ). Short of rejecting the use outwardly, displeased users have to cope with cognitive dissonance by altering their attitude toward the system mentally (Rawstorne, Jayasuriya, \& Caputi, 1998). Thus, in a mandatory setting, intention is not appropriate for assessing their mental acceptance of the system (Nah et al., 2004). For these reasons, models of mandatory use of software should include attitude as a key construct (Brown et al., 2002; Yousafzai et al., 2007b).

A fundamental difference between a mandatory and a volitional system is the organizational consequences that system use carries for the user. For the former, system use is mandated based on 
the organization's aims and objectives. Users are obliged to use the system because that is the only way of accomplishing their daily tasks (Adamson \& Shine, 2003). Performance considerations surrounding the use of the system often are the users' main concern (Taylor \& Todd, 1995). They can lead to reward or punishment for the user. Hence, a user's attitude toward use highly depends on whether he or she believes that such use will enhance his or her job performance, i.e., performance expectancy of the system (Adamson \& Shine, 2003). Brown et al.'s (2002) study of mandatory users even found that performance expectancy completely mediates the effect of effort expectancy (perceived ease-of-use) on attitude, while the relationship between effort expectancy and attitude is not significant. Therefore, we hypothesize that:

H3: Higher level of performance expectancy is related to more positive attitude toward use of the system.

A user of a mandatory system also can differ substantially from a volitional user in terms of his or her social environment of use. Traditionally, the applications studied by the TAM tend to be individual, simpler ones, whereas mandatory systems often are used for tasks that are tightly coupled with other users' tasks (Nah et al., 2004). A user of a mandatory system cannot avoid paying attention to his or her supervisors' and peers' opinions about using the system. Put differently, the user is under the influence of the "subjective norm" (Taylor \& Todd, 1995), or "social influence" in the UTAUT terminology. Subjective norm is defined as a "person's perception that most people who are important to him think he should or should not perform the behavior in question" (Fishbein \& Ajzen, 1975, p. 302). It is part of the Theory of Reasoned Action (TRA), on which the TAM was based. A user may incorporate his or her important referents' beliefs about using the system into his or her own belief structure. Use of the system now takes on an additional social meaning, namely, earning the user credibility in the eyes of the referents. Through this "internalization" process the user will perceive the system as more useful (Venkatesh \& Davis, 2000; Venkatesh et al., 2003). Therefore, we hypothesize that:

\section{H4: Social influence has a positive direct effect on performance expectancy.}

For system use in mandatory environments, some researchers suggested the removal of use from the model because a captive user must use the system (Lee \& Park, 2008; Nah et al., 2004; Rawstorne et al., 1998). This rationale would make sense if use is operationalized as a dichotomous variable (use or not use at all). However, use is often measured as the frequency and intensity of using the system. Such a measure, although not perfect, still can be an objective yardstick of user involvement in system use. In mandatory environments, even if a user mentally rejects a mandatory system, he or she is prohibited from outright refusal to use. The user, however, may underutilize or sabotage the system (Brown et al., 2002; Markus, 1983). This can result in reduced intensity or frequency of use. A significant relationship between attitude and use is supported by various empirical studies (e.g., Compeau \& Higgins, 1991; Lucas, 1975; Porter \& Donthu, 2006; Robey, 1979). Therefore, we hypothesize that:

\section{H5: Positive attitude is related to more use of the system.}

For mandatory systems, users' satisfaction with the system is a more useful measure, especially when evaluating an individual system (as opposed to an IS program) (DeLone \& McLean, 1992). Overall satisfaction is often included in studies of mandatory environments as a mediator or dependent variable (e.g., Adamson \& Shine, 2003; Lee \& Park, 2008; Rawstorne et al., 1998). This satisfaction construct is applied to the system as a whole. In contrast, "characteristics-based" satisfaction is directed toward certain characteristics within the system (Wixom \& Todd, 2005). Just as DeLone and McLean (1992) categorized system output and effectiveness into multiple levels to explain complex relationships, we model satisfaction as occurring at two levels. In addition to the characteristics-based information/system satisfaction, the user will feel an overall sense of satisfaction toward the entirety of the system. Through performance expectancy and attitude, cha- 
racteristics-based satisfaction is related to overall satisfaction. From the perspective of the informing science framework, characteristics-based satisfaction comes from the user being informed, as a client, by information output from the system (instance of informing). Overall satisfaction results not only from this instance and but also from the user's creation of new instance of informing (i.e., using his or her information to inform the organization's clientele). Since system/information satisfaction may be based on an arbitrary set of characteristics (Wixom \& Todd, 2005), having an overall satisfaction construct also provides the benefit of a more general, higherlevel measure of satisfaction.

User attitude toward system use has been associated with user satisfaction (DeLone \& McLean, 1992). Attitude can become a predisposition to respond favorably or unfavorably to a stimulus (in this case, the system) (Ajzen, 1988). A positive attitude is more likely to lead to the feeling of satisfaction with the system. Empirical studies have provided consistent support to a positive, significant relationship between attitude and user satisfaction (e.g., Bin Masrek, 2007; Igbaria \& Nachman, 1990; Rivard \& Huff, 1988). Accordingly, we hypothesize that:

H6: A user's attitude toward system use is positively related to the user's satisfaction with the system.

\section{Organizational Benefits}

The ultimate touchstone of system success is the net benefits the system generates for the organization, including cost savings, expanded markets, and time savings (DeLone \& McLean, 2003). It may be an important concern for organizations to encourage positive attitudinal change or mindful use of the system, but eventually the goal is to bring about increase in net benefits. However, researchers of mandatory software use rarely included net benefits in their models, with one exception being Lee and Park (2008). Their study found that user satisfaction with the system is positively related to perceived market performance. Extensive studies have shown a significant satisfaction-performance relationship (Lee \& Park, 2008). DeLone and McLean's (2003) IS success model incorporated this link, as well as a relationship between system use and net benefits. Use of the system is purported to generate positive or negative net benefits, which, through a feedback loop, can impact future use behavior and satisfaction. Since feedback loops (nonrecursive models) are problematic to test with cross-sectional studies, we hypothesize that use and user satisfaction influence net benefits, but not the other way around:

H7: System use is positively related to net benefits.

H8: Overall satisfaction with the system is positively related to net benefits.

\section{Methodology}

To validate our model, we developed a questionnaire (see Appendix A for items on the questionnaire) and administered it to government employees in a mandatory environment. Items in the questionnaire were based on tested scales in the literature wherever practical. Information quality (3 items), information satisfaction (2 items), and attitude (4 items) were measured using scales from Wixom and Todd (2005). Scales for performance expectancy (4 items), social influence (2 items), and behavioral intention (for alternative models discussed below, 3 items) were taken from Ventatesh et al. (2003). Overall satisfaction (4 items) and net benefits (6 items) were created based on the syntheses in DeLone and McLean $(1992,2003)$. All of the previous items were asked using a 7-point Likert-scale ranging from "strongly disagree" to "strongly agree." In addition, we asked users about the frequency and intensity of their use of systems.

The respondents in this study were employees at the municipal government of a city in southwestern United States. The population of the city was approximately 100,000. The municipal 
government employed over 1,200 employees. We prepared a web-based survey and a senior manager of the city sent a letter to all employees to encourage their participation in the study. The employees were informed that their identity would remain anonymous and that their participation in the study was voluntary and refusal to participate would not adversely affect them in any way. We collected 333 usable responses. This represents a response rate of approximately $27 \%$. Of the respondents, $55.9 \%$ were male and $44.1 \%$ were female.

Our survey covered only those applications whose use was mandatory. General business applications such as Microsoft Word, Excel, PowerPoint, and Publisher were not included in the study. In total, 20 different applications were used across all departments (see Appendix B). For each employee, we asked him or her to select the primary application that he or she used most often and to answer the questions based on his or her experiences with that application. The scope and purpose of these applications ranged from applications that were commonly used by almost all employees to those that were specialized for specific job functions (such as Court Specialists used by the court to track cases, payments, jury pools, and warrants). While most of these applications were commercially available as off-the-shelf packages, some, such as the BRIO Report Writing Tool and LaserFiche, were highly customized to the needs of the city.

Information on the number of respondents per department and application was collected (See Appendix C; ten respondents did not specify the application they used). In addition, we collected some demographic information on the respondents, while preserving their anonymity.

The survey respondents represented a broad spectrum of job types as shown in Table 1. They ranged from office clerks to directors of departments. Similarly, Table 2 shows that all the departments in the City government were well represented.

Table 1. Job Types of Respondents

\begin{tabular}{|c|c|c|}
\hline Type of job & $\begin{array}{l}\text { Number of } \\
\text { Responses }\end{array}$ & Percentage \\
\hline Professional & 73 & $21.9 \%$ \\
\hline Technical paraprofessional & 72 & $21.6 \%$ \\
\hline Office/clerical & 44 & $13.2 \%$ \\
\hline Supervisor & 26 & $7.8 \%$ \\
\hline Field service & 20 & $6.0 \%$ \\
\hline Mid-level manager & 64 & $19.2 \%$ \\
\hline Director/ACM & 16 & $4.8 \%$ \\
\hline Other & 18 & $4.5 \%$ \\
\hline Total & 333 & $100.0 \%$ \\
\hline
\end{tabular}

Non-response bias was assessed by comparing the early and late respondents (Armstrong \& Overton, 1977; De Winter et al., 2005). Independent $t$-tests were performed on early and late response groups to assess whether they differed in terms of job type, years at current job, or number of IT hours worked. The results indicated no significant differences between the two groups at the .05 significance level.

To detect possible common method variance (CMV), we ran Harman's single-factor test (Malhotra, Kim, \& Patil, 2006; Podsakoff, MacKenzie, Lee, \& Podsakoff, 2003) by performing an exploratory factor analysis on all the 27 items in the model. The unrotated solution revealed that more than one factor was extracted and none of the factors explained an overwhelming portion of the variance. Therefore, CMV was not a serious concern. After all, Malhotra, Kim, and Patil 
(2006), based on retests of prior correlations, concluded that for IS studies, CMV does not inflate correlations in an alarming manner.

Table 2. Distribution of Respondents by Department

\begin{tabular}{|c|c|c|}
\hline Department & $\begin{array}{l}\text { Number of } \\
\text { Responses }\end{array}$ & $\begin{array}{r}\text { Percent of total } \\
\text { Responses }\end{array}$ \\
\hline Public Safety & 60 & $18.0 \%$ \\
\hline Water, Wastewater \& Drainage & 41 & $12.3 \%$ \\
\hline Library & 33 & $9.9 \%$ \\
\hline Budget \& Fiscal Operations & 33 & $9.9 \%$ \\
\hline Electric & 24 & $7.2 \%$ \\
\hline Technology Services & 18 & $5.4 \%$ \\
\hline Parks and KDB & 15 & $4.5 \%$ \\
\hline Solid Waste, Landfill \& Recycling & 14 & $4.2 \%$ \\
\hline Customer Service & 12 & $3.6 \%$ \\
\hline Community/Downtown/Economic Development & 11 & $3.3 \%$ \\
\hline Planning and Building Inspection & 10 & $3.0 \%$ \\
\hline General Government & 10 & $3.0 \%$ \\
\hline Human Resources & 9 & $2.7 \%$ \\
\hline Other & 43 & $2.1 \%$ \\
\hline Total & 333 & $100.0 \%$ \\
\hline
\end{tabular}

\section{Data Analysis}

We performed a partial least squares analysis (PLS) on the collected responses. PLS has some major advantages over covariance-based methods such as LISREL, EQS, and AMOS. It avoids two major problems of covariance-based modeling - inadmissible solutions and factor indeterminacy (Fornell \& Bookstein, 1982). To obtain sufficient power, PLS requires a sample size that is ten times the number of regressions in either (a) the block with the largest number of formative indicators or (b) the endogenous latent variable with the largest number of exogenous latent variables impacting it, whichever is larger (Chin \& Newsted, 1999). PLS is, in essence, a process of iterative multiple regression analyses. Thus, power calculation for PLS is done by looking at one subset of regression ("block") at a time, for which power calculation methods for multiple regression such as J. Cohen's (1988) tables can be used (Liang, Saraf, Hu, \& Xue, 2007). Use of the G*Power 3 automated power calculation program (Faul, Erdfelder, Lang, \& Buchner, 2007) showed that to have .80 power to detect medium size effect at the .05 significance level, a sample size of 77 was required. Since we have 333 responses, sufficient power was provided with this sample size.

\section{Assessment of Measurement Model}

The adequacy of the measurement model is determined by examining reliability and convergent and discriminant validities (Hulland, 1999). As shown in Table 3, the alpha coefficients of all constructs are above the generally agreed-upon lower limit of .7 (Hair, Black, Babin, Anderson, \& Tatham, 2006), showing a satisfactory degree of reliability. 
Table 3. Cronbach's Alpha

\begin{tabular}{cll}
\hline & \multicolumn{1}{c}{ Construct } & Alpha \\
\hline IQ & Information Quality & 0.9650 \\
IS & Information Satisfaction & 0.9738 \\
PE & Performance Expectancy & 0.9622 \\
SI & Social Influence & 0.8895 \\
AT & Attitude & 0.9190 \\
USE & System Use & 0.7620 \\
OS & Overall Satisfaction & 0.9283 \\
NB & Net Benefits & 0.9621 \\
\hline
\end{tabular}

Table 4. Descriptive Statistics of Item Loadings

\begin{tabular}{|c|c|c|c|c|c|}
\hline & Mean & Mean (Bootstrap) & S.D. & S.E. & t-Statistic \\
\hline IQ1 & 0.9631 & 0.9631 & 0.0068 & 0.0068 & 142.5962 \\
\hline IQ2 & 0.9767 & 0.9766 & 0.0051 & 0.0051 & 189.7937 \\
\hline IQ3 & 0.9605 & 0.9600 & 0.0067 & 0.0067 & 144.2840 \\
\hline IS1 & 0.9874 & 0.9875 & 0.0023 & 0.0023 & 435.3855 \\
\hline IS2 & 0.9868 & 0.9869 & 0.0026 & 0.0026 & 375.3152 \\
\hline PE1 & 0.9201 & 0.9207 & 0.0128 & 0.0128 & 72.1133 \\
\hline PE2 & 0.9636 & 0.9638 & 0.0056 & 0.0056 & 172.1051 \\
\hline PE3 & 0.9596 & 0.9595 & 0.0068 & 0.0068 & 142.1447 \\
\hline PE4 & 0.9478 & 0.9479 & 0.0078 & 0.0078 & 121.1052 \\
\hline SI1 & 0.9373 & 0.9352 & 0.0199 & 0.0199 & 47.0877 \\
\hline $\mathrm{S} 12$ & 0.9595 & 0.9600 & 0.0081 & 0.0081 & 118.2809 \\
\hline AT1 & 0.8384 & 0.8384 & 0.0216 & 0.0216 & 38.8674 \\
\hline AT2 & 0.8769 & 0.8755 & 0.0213 & 0.0213 & 41.1900 \\
\hline AT3 & 0.9284 & 0.9286 & 0.0083 & 0.0083 & 111.7555 \\
\hline AT4 & 0.9435 & 0.9434 & 0.0065 & 0.0065 & 145.5123 \\
\hline USE1 & 0.8876 & 0.8610 & 0.1219 & 0.1219 & 7.2798 \\
\hline USE2 & 0.9093 & 0.8962 & 0.0972 & 0.0972 & 9.3536 \\
\hline OS1 & 0.9099 & 0.9101 & 0.0135 & 0.0135 & 67.2834 \\
\hline OS2 & 0.9151 & 0.9157 & 0.0146 & 0.0146 & 62.8064 \\
\hline os3 & 0.9007 & 0.8998 & 0.0209 & 0.0209 & 43.1194 \\
\hline OS4 & 0.9025 & 0.9029 & 0.0098 & 0.0098 & 92.4140 \\
\hline NB1 & 0.9172 & 0.9169 & 0.0112 & 0.0112 & 81.5316 \\
\hline NB2 & 0.9406 & 0.9408 & 0.0074 & 0.0074 & 126.6448 \\
\hline NB3 & 0.8952 & 0.8948 & 0.0141 & 0.0141 & 63.3005 \\
\hline NB4 & 0.9316 & 0.9314 & 0.0107 & 0.0107 & 86.6879 \\
\hline NB5 & 0.9141 & 0.9139 & 0.0113 & 0.0113 & 81.1839 \\
\hline NB6 & 0.9026 & 0.9024 & 0.0143 & 0.0143 & 62.9398 \\
\hline
\end{tabular}


Koh, Prybutok, Ryan, \& Wu

Convergent validity provides a measure of the variance shared between a construct and its indicators. It is gauged by examining whether items load with significant $t$-values on its construct and the significance level of .05 or higher is desired (Gefen \& Straub, 2005). Table 4 shows that our items support the contention of convergent validity. As can be seen from the table, all of these loadings are at the .001 significance level.

Descriminant validity is high when each within-construct item loads highly on the construct it is intended to measure and cross-loadings are lower than the within-construct item loadings. In our study, this is observed in the loadings and cross-loadings (Table 5).

Table 5. Loadings and Cross-Loadings

\begin{tabular}{ccccccccc}
\hline & IQ & IS & PE & SI & AT & USE & OS & NB \\
\hline IQ1 & $\mathbf{0 . 9 6 3 1}$ & 0.8371 & 0.7497 & 0.4050 & 0.7949 & 0.0551 & 0.7757 & 0.8265 \\
IQ2 & $\mathbf{0 . 9 7 6 7}$ & 0.8623 & 0.7260 & 0.3871 & 0.7644 & 0.0490 & 0.7756 & 0.8218 \\
IQ3 & $\mathbf{0 . 9 6 0 5}$ & 0.8661 & 0.7769 & 0.4365 & 0.7789 & 0.0588 & 0.7829 & 0.8443 \\
IS1 & 0.8809 & $\mathbf{0 . 9 8 7 4}$ & 0.7715 & 0.4479 & 0.8105 & 0.0809 & 0.8187 & 0.8878 \\
IS2 & 0.8656 & $\mathbf{0 . 9 8 6 8}$ & 0.7467 & 0.4187 & 0.8040 & 0.0704 & 0.8210 & 0.8794 \\
PE1 & 0.7593 & 0.7376 & $\mathbf{0 . 9 2 0 1}$ & 0.4289 & 0.7598 & 0.0452 & 0.7794 & 0.7423 \\
PE2 & 0.7440 & 0.7377 & $\mathbf{0 . 9 6 3 6}$ & 0.4271 & 0.7816 & 0.1246 & 0.8019 & 0.7627 \\
PE3 & 0.7044 & 0.7075 & $\mathbf{0 . 9 5 9 6}$ & 0.4198 & 0.7603 & 0.1048 & 0.7567 & 0.7403 \\
PE4 & 0.7364 & 0.7325 & $\mathbf{0 . 9 4 7 8}$ & 0.4642 & 0.7882 & 0.1251 & 0.7776 & 0.7704 \\
SI1 & 0.3450 & 0.3563 & 0.3856 & $\mathbf{0 . 9 3 7 3}$ & 0.3533 & 0.1371 & 0.3117 & 0.4193 \\
SI2 & 0.4487 & 0.4660 & 0.4769 & $\mathbf{0 . 9 5 9 5}$ & 0.4917 & 0.1320 & 0.4283 & 0.5048 \\
AT1 & 0.7753 & 0.7470 & 0.7969 & 0.4318 & $\mathbf{0 . 8 3 8 4}$ & 0.0346 & 0.7274 & 0.7701 \\
AT2 & 0.6189 & 0.6334 & 0.6649 & 0.4235 & $\mathbf{0 . 8 7 6 9}$ & 0.1290 & 0.6559 & 0.6677 \\
AT3 & 0.6954 & 0.7465 & 0.6941 & 0.3986 & $\mathbf{0 . 9 2 8 4}$ & 0.0859 & 0.7731 & 0.7426 \\
AT4 & 0.7874 & 0.7946 & 0.7605 & 0.3753 & $\mathbf{0 . 9 4 3 5}$ & 0.1112 & 0.8345 & 0.7964 \\
USE1 & 0.0358 & 0.0652 & 0.1005 & 0.1296 & 0.0807 & $\mathbf{0 . 8 8 7 6}$ & 0.0956 & 0.0808 \\
USE2 & 0.0638 & 0.0724 & 0.0900 & 0.1248 & 0.0972 & $\mathbf{0 . 9 0 9 3}$ & 0.1433 & 0.0806 \\
OS1 & 0.7030 & 0.7219 & 0.7864 & 0.2987 & 0.7451 & 0.1425 & $\mathbf{0 . 9 0 9 9}$ & 0.7205 \\
OS2 & 0.6842 & 0.7150 & 0.7163 & 0.3543 & 0.7444 & 0.1178 & $\mathbf{0 . 9 1 5 1}$ & 0.7254 \\
OS3 & 0.7239 & 0.7173 & 0.7172 & 0.3470 & 0.7087 & 0.1011 & $\mathbf{0 . 9 0 0 7}$ & 0.7155 \\
OS4 & 0.7985 & 0.8442 & 0.7592 & 0.4268 & 0.8275 & 0.1244 & $\mathbf{0 . 9 0 2 5}$ & 0.8553 \\
NB1 & 0.8027 & 0.8148 & 0.7446 & 0.4223 & 0.7913 & 0.0916 & 0.7946 & $\mathbf{0 . 9 1 7 2}$ \\
NB2 & 0.7945 & 0.8347 & 0.7375 & 0.4527 & 0.7894 & 0.1245 & 0.7969 & $\mathbf{0 . 9 4 0 6}$ \\
NB3 & 0.7641 & 0.7766 & 0.6953 & 0.4236 & 0.7495 & 0.0781 & 0.7292 & $\mathbf{0 . 8 9 5 2}$ \\
NB4 & 0.8062 & 0.8315 & 0.7190 & 0.4490 & 0.7705 & 0.1023 & 0.7672 & $\mathbf{0 . 9 3 1 6}$ \\
NB5 & 0.7794 & 0.8212 & 0.7496 & 0.4681 & 0.7381 & 0.0412 & 0.7368 & $\mathbf{0 . 9 1 4 1}$ \\
NB6 & 0.7808 & 0.8450 & 0.7310 & 0.4886 & 0.7389 & 0.0528 & 0.7701 & $\mathbf{0 . 9 0 2 6}$ \\
\hline & & & & & & & & \\
\hline
\end{tabular}

Analysis of average variance extracted (AVE) is another way to test the discriminant validity of constructs. Discriminant validity is evident when a construct has an AVE whose square root is above .50 and higher than any correlation among any pairs of constructs (Chin, 1998; Gefen \& Straub, 2005). Table 6 displays the square roots of the AVEs of the constructs along the diagonal. 
The off-diagonal terms are the correlations between constructs. As can be seen from the table, the constructs demonstrate sufficient discriminant validity.

Table 6. AVEs and Correlations between Constructs

\begin{tabular}{ccccccccc}
\hline & IQ & IS & PE & SI & AT & USE & OS & NB \\
\hline IQ & $\mathbf{0 . 9 6 6 7}$ & & & & & & & \\
IS & 0.8847 & $\mathbf{0 . 9 8 7 1}$ & & & & & & \\
PE & 0.7768 & 0.7692 & $\mathbf{0 . 9 4 7 9}$ & & & & & \\
SI & 0.4237 & 0.4391 & 0.4592 & $\mathbf{0 . 9 4 8 4}$ & & & & \\
AT & 0.8060 & 0.8178 & 0.8152 & 0.4527 & $\mathbf{0 . 8 9 7 8}$ & & & \\
USE & 0.0561 & 0.0767 & 0.1056 & 0.1414 & 0.0994 & $\mathbf{0 . 8 9 8 5}$ & & \\
OS & 0.8048 & 0.8305 & 0.8220 & 0.3961 & 0.8372 & 0.1342 & $\mathbf{0 . 9 0 7 1}$ & \\
NB & 0.8595 & 0.8952 & 0.7957 & 0.4914 & 0.8325 & 0.0898 & 0.8359 & $\mathbf{0 . 9 1 7 0}$ \\
\hline
\end{tabular}

\section{Assessment of Structural Model}

We then assess the structural model. The standardized solution is shown in Table 7.

Table 7. Standardized Path Coefficients and Significance

\begin{tabular}{|c|c|c|c|}
\hline Path & Coefficient & Path & Coefficient \\
\hline $\mathrm{H} 1: \mathrm{IQ} \rightarrow \mathrm{IS}$ & $.885^{\star \star \star}$ & H5: AT $\rightarrow$ USE & $.0 .099^{*}$ \\
\hline $\mathrm{H} 2: \mathrm{IS} \rightarrow \mathrm{PE}$ & $.703^{\star * *}$ & H6: AT $\rightarrow$ OS & $.837^{* * *}$ \\
\hline H3: PE $\rightarrow$ AT & $.815^{* * *}$ & $\mathrm{H} 7:$ USE $\rightarrow$ NB & -.023 n.s. \\
\hline $\mathrm{H} 4: \mathrm{SI} \rightarrow \mathrm{PE}$ & $.150^{* *}$ & H8: OS $\rightarrow$ NB & $.839^{* * *}$ \\
\hline
\end{tabular}

As can be seen in the table, all of the hypothesized relationships, except the one between use and net benefits are supported. Figure 5 presents the results graphically. The model explains a large portion of variances in the final criterion variable (net benefits, $\mathrm{R}^{2}=.699$ ), as well as most of the mediating variables (information satisfaction, $\mathrm{R}^{2}=.783$; performance expectancy, $\mathrm{R}^{2}=.610$; attitude, $\mathrm{R}^{2}=.665$; overall satisfaction toward system use, $\mathrm{R}^{2}=.701$ ). The $\mathrm{R}^{2}$ for use, however, is a negligible .01 . The next section discusses the structural model results in more detail.

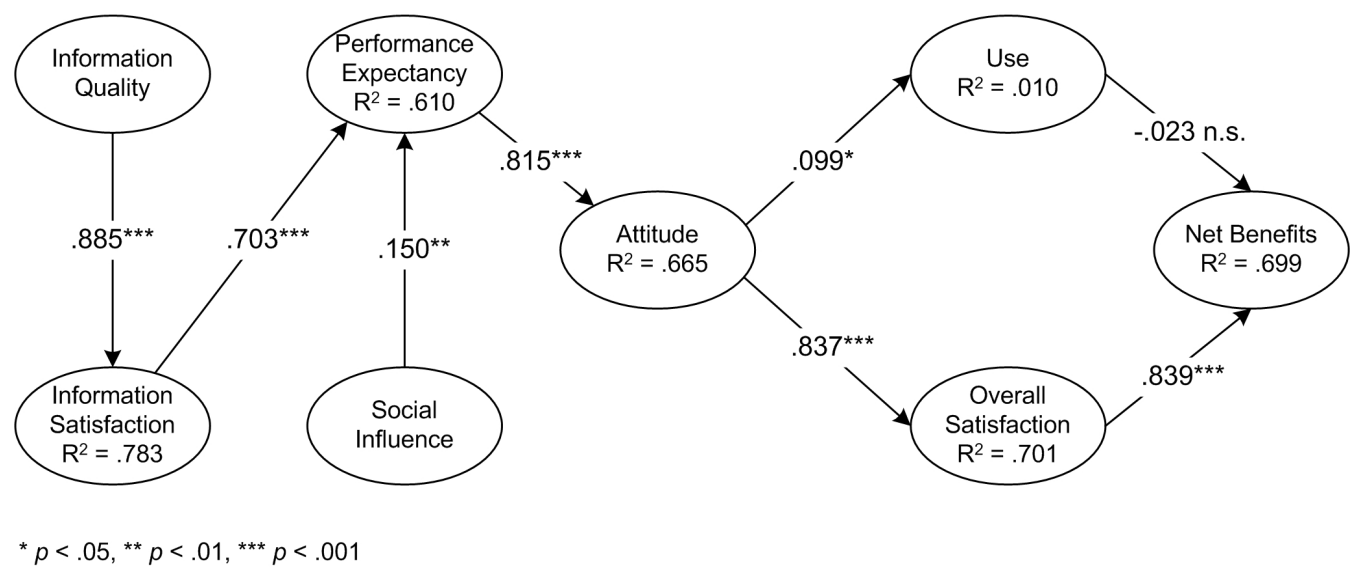

Figure 5. Standardized Path Coefficients and Significance 


\section{Discussion}

Data analysis results support most of our hypotheses about relationships in mandatory software use environments. Important prior studies had varied focuses along the chain of relationships from the quality of information output all the way to the realization of net benefits. Thanks to the "lantern" research (E. Cohen, 2009) approach, we were able to integrate and bridge findings from them. As a result, we gained some important insights.

One such insight beseeches researchers to seriously consider which pivotal construct(s) to study when using the TAM to explain mandatory software use. The TAM was developed with voluntary use in mind and based on a theory to explain volitional behaviors (TRA). The explanatory value of the TAM ultimately rests on its efficacy in predicting the intention to use a system. In terms of theorizing, the TAM was established on a causal chain that centers on intention (the attitude-intention-behavior link in the original TAM or the intention-behavior link in the parsimonious TAM, TAM2, and TAM3).

With volitional users replaced by captive users in mandatory environments, first to be reconsidered is whether a model about mandatory use should include and/or end with system use as the ultimate criterion variable. Second, since user intention is rendered powerless in such environments, could it be that some other variable, instead of intention, is more indicative of users' psychological reactions to the influencing factors in the environment? Put differently, those factors still exert influences on the users. However, now that users cannot refuse to use the system, those influences manifest not as users' intention but as something else. Our study results suggest that attitude may be a valid "replacement variable" for intention.

To test this, we compared two variations of our model. First, we replaced attitude with intention. Based on the relationships in the TAM, we additionally modeled that social influence is positively related to intention (Venkatesh et al., 2003). The standardized results (Figure 6) demonstrate that: (a) as suggested by the TAM, performance expectancy predicts intention. However, in this mandatory environment, the coefficient is .402 , less than half of that for attitude $(.815$, Figure 5); (b) contrary to the central TAM proposition, intention is not a significant predictor of use; (c) although the link between intention and overall satisfaction also is significant, intention only explains $18.9 \%$ of the variance in overall satisfaction, as opposed to the $70.1 \%$ that attitude explains.

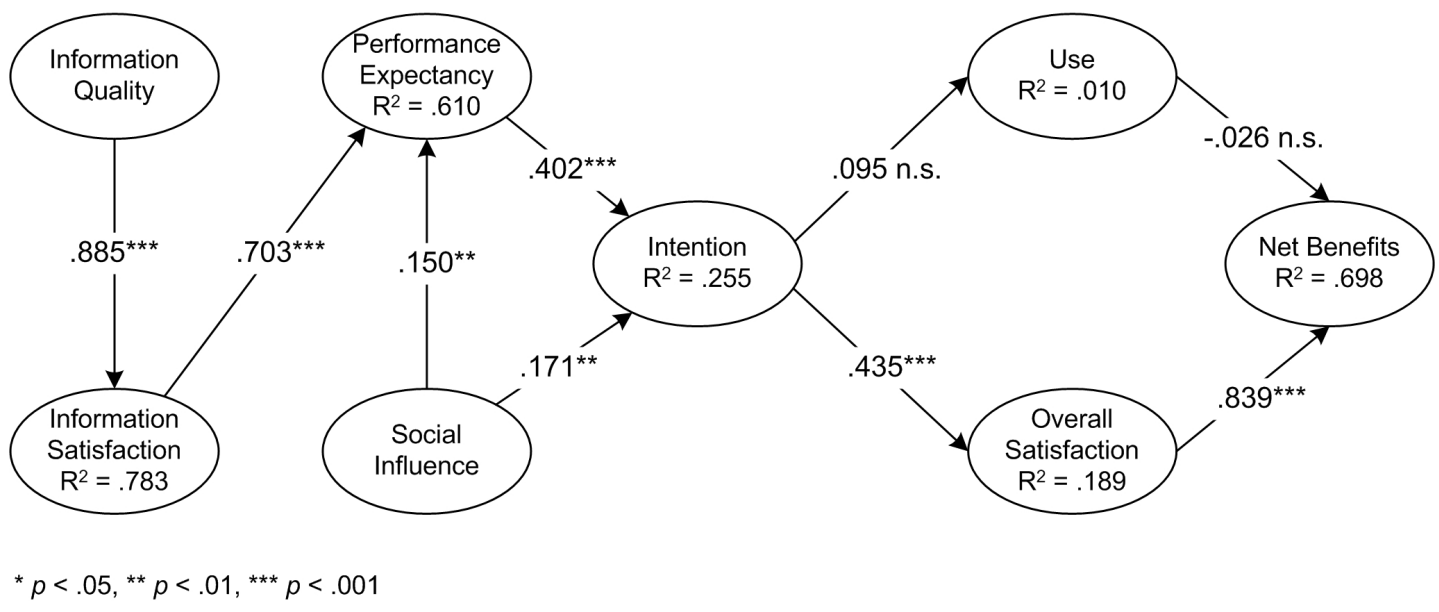

Figure 6. Alternative Model 1 (Replacing Attitude with Intention) 
Next, we also tested another alternative model, this time including both intention and attitude in the model (Figure 7). Since earlier versions of the TAM posited that attitude is a predictor of intention, we added a relationship between the two. Test of this model shows that: (a) diametric to the TAM proposition, in the mandatory environment, attitude no longer predicts intention. In other words, when use is mandated, the attitude of users really does not or cannot matter because they are required to use the system regardless of their affective feeling toward the system; (b) with the two constructs placed alongside each other, performance expectancy still is a much stronger predictor of attitude (beta $=.817, p<.001$ ) than of intention (beta $=.333, p<.01$ ); (c) with the addition of attitude, the percentage of explained variance of overall satisfaction increases substantially from $18.9 \%$ to $70.7 \%$ (on par with the $70.1 \%$ in Figure 5 ); (d) attitude is a much stronger predictor of overall satisfaction (beta $=.799, p<.001$ ) than intention is (beta $=$ $.087, p<.01$ ); (e) with the addition of intention, attitude is no longer a significant predictor of use. However, note that in all three models compared, the $\mathrm{R}^{2}$ for use is only $1 \%$. This may suggest that in mandatory environments, use is indeed irrelevant. Viewed from another angle, it may be that current theorization based on TAM constructs is not effective in explaining the variance in use.

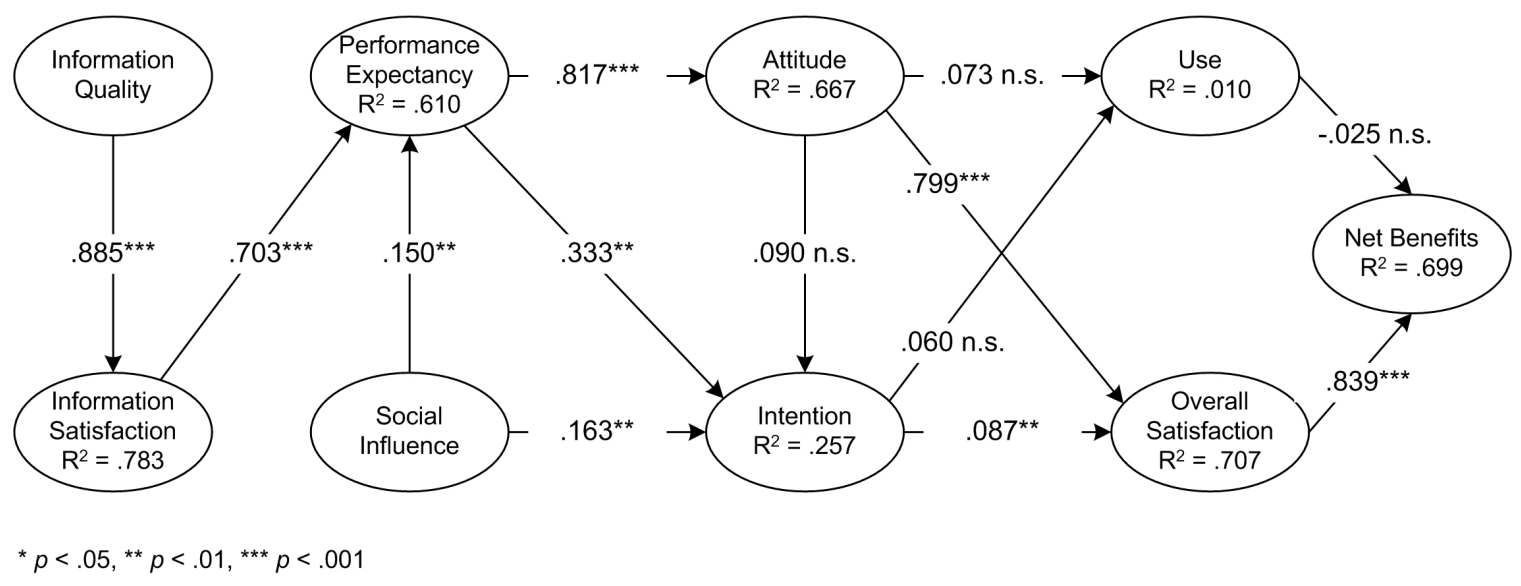

Figure 7. Alternative Model 2 (Side-by-Side Comparison of Attitude and Intention)

To sum up, in mandatory environments, the intention-centered causal link that is the mainstay of the TAM no longer holds. Neither supported is the quintessential hypothesis of the TAM that intention is a strong predictor of use. Therefore, for mandatory use of software, the explanatory power provided by the TAM comes not from the causal chain centered on intention, but from psychological constructs such as performance expectancy and attitude. Our findings show that in mandatory settings, the relationships among these constructs as postulated by the TAM indeed are still significant. We recommend that future researchers of mandatory use, if employing constructs from the TAM literature, include attitude toward system use as a key variable in their theory development.

This study contributes to our understanding of the informing science framework. First, E. Cohen provides a one-sentence definition of informing science - it is about how to "provide their clientele with information in a form, format, and schedule that maximizes its effectiveness" (E. Cohen, 1999 , p. 215). He also recommends the examination of a person's psychological and affective factors as well as the context and environment in which the person operates. We find it imperative to explore the mandatory computing environment because it is still significantly underexplored despite its omnipresence today.

Second, our study demonstrates the effectiveness of the informing science framework in generating insights that may be overlooked if a "laser" research (E. Cohen, 2009) approach is taken. As 
can be seen from our review of extant literature, researchers, usually under the strong influence of the traditional, "laser" school of thought for epistemology and research methodology, tend to focus on a subset of a larger picture. A common TAM modeling pattern is to stop at use. By following the principles of informing science, especially by conceiving the system at multiple levels of abstraction, we realize that the typical TAM-like approach only focuses on one level of abstraction. However, in mandatory environments, the first-level abstraction, namely, informing via system use, is decreed and strongly enforced. Notwithstanding, the client in this informing instance, the captive users, should not be assumed to be passive. In addition, the mandatory nature of system use does not necessarily create a uniform outcome from the informing instance. One critical factor that causes variation in the outcome of informing is the quality of the information generated by the system. Where, inside the complexity of user psychology, will we see the consequences of factors like this? If we dwell on the typical TAM criterion variables, we may not be able to detect the most meaningful consequences. With intention and use held relatively constant in mandatory environments, they are not likely to be the constructs whose variances sufficiently reflect the impact of key factors in the environment. This can be seen in the small $\mathrm{R}^{2} \mathrm{~s}$ of intention and use in our models (e.g., Figure 6).

If we conceive a higher level of abstraction, i.e., creation of a new informing instance, then it is easy for us to see the impact of those factors. At this level, the client becomes the informer while serving the organization's clientele. The main goal of the information system is not achieved in the first informing instance, to which intention and use are related. The second-level abstraction explicates the true mission of information systems - to serve the clientele and thus to beget benefits for the organization, including a better relationship with the clientele. What connects the two levels of informing instances is the user's satisfaction. An employee who is satisfied with using the system is more likely to use the system wholeheartedly and correctly and, in turn, more likely to contribute to the success of the second-level informing instance. A strong predictor of the users' overall satisfaction is their attitude toward system use. These relationships are evidenced by the strong relationships between attitude and overall satisfaction (H6) and between satisfaction and net benefits (H8) in our model.

In short, adopting the informing science framework, we visualize the system as being used for two informing instances. As the result, we are able to integrate important constructs into our model. This is particularly relevant to mandatory systems because they are often decreed to achieve the goals of the higher-level instance of informing.

The third level of abstraction is about changing system design in an informed way. Information systems researchers strive to uncover critical variables that explain user psychology and behaviors. System designers avidly pursue methods to improve system quality and outcome. Both groups in fact share the common goal of designing better systems that users are more willing and able to use. Our research findings also furnish some insights that can be of help at the third level of abstraction. They are discussed in the implications section.

\section{Implications}

Organizations usually are in power to push through the use of mandatory systems. Short of quitting their jobs, employees do not seem to be in a good bargaining position. However, mandatory use potentially can cause dissonance between employees' expectations and the reality of the systems, leading to negative attitude. Therefore, an important question for designers of these systems to ask is, How do we ensure that the employees are well informed by and also develop a positive attitude toward the systems?

For future research on mandatory environments, we suggest that attitude, instead of intention or use, be used as a key variable. Moreover, the determinants of the psychological constructs war- 
rant further investigation than was previously done with the TAM. Our findings bolster the relationships posited in Wixom and Todd's (2005) model. Specifically, information quality significantly affects information satisfaction, which, in turn, impacts performance expectancy.

Key factors that may impact the relevant psychological constructs thus need to be scrutinized. In this study we extend the Wixom and Todd (2005) model by exploring the role played by social influence. This is necessary because in mandatory settings, the utility value of the system is of particular importance. A user's performance using the system impacts and is impacted by other users' performance. In other words, the users are interrelated to each other. Thus, when a user forms an attitude toward the system, it is inevitably under the influence of what his or her superiors and peers think about the consequences of his or her use of the system. Indeed, our data analysis shows that social influence significantly affects a user's behavioral attitude.

For system adoption researchers, this study can be helpful by proposing and validating a model that is theoretically grounded and conceptually consistent with the reality of mandatory system use. Previous models of mandatory information system use typically apply a variant of TAM to mandatory and volitional environments indiscriminately (e.g., Hartwick \& Barki, 1994). This practice is prone to mixed findings. It also causes a conceptual irony in that the intention construct still takes on a central role in the models despite the requirement in mandatory environments that the users have to use the system whether they prefer to use it or not. Our proposed model resolves this irony by focusing exclusively on mandatory environments and removing the intention construct. We test its validity by examining two alternative models that replace attitude with intention (Alternative Model 1) or compare the effects of attitude and intention side by side (Alternative Model 2). Both models fail to support the attitude-intention-use cause link in the TAM, thus testifying to the need to modify the TAM to explain mandatory use. These results are consistent with a similar finding in Nah et al. (2004), which examines a mandatory ERP environment.

Our study has two major implications for system designers. For one, the first step in building a system that users will like is to ensure a high-quality system. Mandatory systems typically are not "hedonic systems" (Van der Heijden, 2004) and the major driver for user attitude is how well they facilitate users' tasks. Previous studies show that system quality and information quality strongly influence the quality of business operations (Prybutok \& Spink, 1999; Salmela, 1997). Thus, if system engineers are diligent in ensuring the quality of system output, the resultant system is more likely to please users, hence reducing users' psychological objection to the system or to the loss of volition. This can be done by implementing prototyping techniques to extract user requirements precisely (e.g., Davis \& Venkatesh, 2004), following structural development methodologies such as software process improvement (SPI) (Green, Hevner, \& Collins, 2005), etc. However, designers should bear in mind that high-quality information does not automatically lead to high business value. The additional ingredient for success is close collaboration between system designers and managers (Salmela, 1997). Therefore, in addition to the technical skills required for ensuring information and system quality, a successful system engineer must acquire dexterity in communicating with business managers.

Also, given our findings about the impact of social influence on user attitude, we suggest that business managers pay special attention to creating the positive effects of social influence. Implementing mandatory systems may seem deceptively easy because use in such environments is decreed. This often is accompanied by exaltation of the benefits of the system. However, regardless of the quality of the system output, sooner or later the employee will detect management's true perception of the system. If standing behind the system is lip service or lack of faith, employees will form passive or negative attitudes toward system use. Therefore, to foster positive employee attitude, the organization should take a positive position toward system use and provide organization-wide support, including a large training program (Schepers \& Wetzels, 2007). Also, 
for mandatory systems, users usually do not have much say in the system adoption decision process, which can easily cause users to doubt the imposed system. Subjective norm is found to help to cultivate users' trust in information systems (Li, Hess, \& Valacich, 2006). Thus, management's expression of their genuine belief in the quality and benefits of the new system can dissipate employees' doubt and encourage positive attitudes.

\section{Limitations}

There are a few limitations to our study. Given the constraints of our data collection process, we were unable to gather more detailed usage information. Our measurement of the use construct was insufficient to capture the gamut of system use. Burton-Jones and Straub (2008) suggested that use is a much more complex construct than many researchers perceive it to be. The exact measure of use needs to be determined by analyzing the relative importance of three elements system, user, and task - to the phenomenon that a researcher sets out to study. Therefore, our future study will adopt more focused measures of use to better gauge those aspects of use that are unique to mandatory use.

In addition, it would be interesting to study the consequences of users' behavioral attitudes in mandatory settings. These may not be reflected in explicit usage but rather subtly in the degree to which users incorporate system use into their job performance. Our current study lacked the scales to capture the finesse of user behaviors in this respect.

The external validity of our study may be limited because it was conducted in a municipal government environment. It was specific to the operational characteristics of the local government. For example, the variety of departments involved was fairly wide, including a health department, a power generating utility company, a trash collection company, the city police, etc. Whereas this variety lends some support to the external validity of our findings in that some of departments resembled for-profit operations, the applicability of our findings to private sector organizations remains to be tested in future studies.

\section{Conclusion}

In this paper, we develop a model for mandatory system use by adopting an informing science perspective that views systems at three levels of abstraction. We argue that mandating use only ensures that a particular system is implemented for the informing instance that takes place at the first level of abstraction. Good quality information output provided to the user helps to form positive user attitude, which is much needed for creating new informing instances for the organization's clientele. Analysis of empirical data collected from municipal government users lends support to our model. We recommend that future researchers further investigate the effects of attitude, instead of intention, on mandatory use. Our study also contributes to the third level of abstraction by offering insights into system design.

\section{References}

Adamson, I., \& Shine, J. (2003). Extending the new technology acceptance model to measure the end user information systems satisfaction in a mandatory environment: A bank's treasury. Technology Analysis and Strategic Management, 15(4), 441-455.

Ajzen, I. (1988). Attitudes, personality and behavior. Chicago, IL: The Dorsey Press.

Ajzen, I., \& Fishbein, M. (1980). Understanding attitudes and predicting social behavior. Englewood Cliffs, NJ: Prentice-Hall.

Armstrong, J. S., \& Overton, T. S. (1977). Estimating nonresponse bias in mail surveys. Journal of Marketing Research, 14, 396-402. 
Bin Masrek, M. N. (2007). Measuring campus portal effectiveness and the contributing factors. CampusWide Information Systems, 24(5), 342-353.

Brown, S. A., Massey, A. P., Montoya-Weiss, M. M., \& Burkman, J. R. (2002). Do I really have to? User acceptance of mandated technology. European Journal of Information Systems, 11, 283-295.

Burton-Jones, A., \& Straub, D. W. (2008). Reconceptualizing system usage: An approach and empirical test. Information Systems Research, 17(3), 228-248.

Chin, W. W. (1998). The partial least square approach for structural equation modeling. In G. A. Marcoulides (Ed.), Modern methods for business research (pp. 295-336). Mahwah, NJ: Lawrence Erlbaum Associates.

Chin, W. W., \& Newsted, P. R. (1999). Structural equation modeling analysis with small samples using partial least squares. In R. H. Hoyle (Ed.), Statistical strategies for small smple research (pp. 307-341). Thousand Oaks, CA: Sage.

Cohen, J. (1988). Statistical power analysis for the behavioral sciences (2nd ed.). Hillsdale, NJ: Lawrence Erlbaum Associates.

Cohen, E. B. (1999). Reconceptualizing information systems as a field of the transdiscipline informing science: From ugly duckling to swan. Journal of Computing and Information Technology, 7(3), 213219.

Cohen, E. B. (2000). Failure to inform: Errors in information systems. Paper presented at the Americas Conference on Information Systems, Long Beach, CA.

Cohen, E. B. (2009). A philosophy of informing science. Informing Science: the International Journal of an Emerging Transdiscipline, 12, 1-15. Retrieved from http://www.inform.nu/Articles/Vol12/ISJv12p001-015Cohen399.pdf

Compeau, D. R., \& Higgins, C. A. (1991). A social cognitive theory perspective on individual reactions to computing technology. Paper presented at the Twelfth International Conference on Information Systems, New York.

Davis, F. D. (1989). Perceived usefulness, perceived ease of use, and user acceptance of information technology. MIS Quarterly, 13(3), 319-340.

Davis, F. D., Bagozzi, R. P., \& Warshaw, P. R. (1989). User acceptance of computer technology: A comparison of two theoretical models. Management Science, 35(8), 982-1003.

Davis, F. D., \& Venkatesh, V. (2004). Toward preprototype user acceptance testing of new information systems: Implications for software project management. IEEE Transaction on Engineering Management, 50(1), 31-46.

De Winter, A. F., Oldehinkel, A. J., Veenstra, R., Brunnekreef, J. A., Verhulst, F. C., \& Ormel, J. (2005). Evaluation of non-response bias in mental health determinants and outcomes in a large sample of preadolescents. European Journal of Epidemiology, 20, 173-181.

DeLone, W. H., \& McLean, E. R. (1992). Information systems success: The quest for the dependent variable. Information Systems Research, 3(1), 60-95.

DeLone, W. H., \& McLean, E. R. (2003). The DeLone and McLean Model of information systems success: A ten-year update. Journal of Management Information Systems, 19(4), 9-30.

Faul, F., Erdfelder, E., Lang, A.-G., \& Buchner, A. (2007). G*Power 3: A flexible statistical power analysis program for the social, behavioral, and biomedical sciences. Behavior Research Methods, 39(2), 175191.

Fishbein, M., \& Ajzen, I. (1975). Belief, attitude, intention, and behavior: An introduction to theory and research. Reading, MA: Addison-Wesley.

Fornell, C., \& Bookstein, F. (1982). Two structural equation models: LISREL and PLS applied to consumer exit-voice theory. Journal of Marketing Research, 18(1), 440-452. 
Gefen, D., \& Straub, D. W. (2005). A practical guide to factorial validty using PLS-Graph: Tutorial and annotated example. Communications of the AIS, 16, 91-109.

Gill, T. G., \& Bhattacherjee, A. (2007). The informing sciences at a crossroads: The role of the client. Informing Science: the International Journal of an Emerging Transdiscipline, 10, 17-39. Retrieved from http://www.inform.nu/Articles/Vol10/ISJv10p017-039Gill317.pdf

Gill, T. G., \& Bhattacherjee, A. (2009). Whom are we informing? Issues and recommendations for MIS research from an informing science perspective. MIS Quarterly, 33(2), 217-235.

Green, G. C., Hevner, A. R., \& Collins, R. W. (2005). The impacts of quality and productivity perceptions on the use of software process improvement innovations. Information and Software Technology, 47, 543-553.

Hair, J. F., Black, W. C., Babin, B. J., Anderson, R., \& Tatham, R. L. (2006). Multivariate data analysis (6th ed.). Upper Saddle River, NJ: Prentice Hall.

Hartwick, J., \& Barki, H. (1994). Explaining the role of user participation in information system use. Management Science, 40(4), 440-465.

Hulland, J. (1999). Use of partial least squares (PLS) in strategic management research: A review of four recent studies. Strategic Management Journal, 20(2), 195-204.

Igbaria, M., \& Nachman, S. A. (1990). Correlates of user satisfaction with end user computing: An exploratory study. Information \& Management, 19, 73-82.

Jensen, T. B., \& Aanestad, M. (2007). Hospitality and hostility in hospitals: A case study of an ERP adoption among surgeons. European Journal of Information Systems, 16, 672-680.

Lee, T. M., \& Park, C. (2008). Mobile technology usage and B2B market performance under mandatory adoption. Industrial Marketing Management, 37, 833-840.

Li, X., Hess, T. J., \& Valacich, J. S. (2006). Using attitude and social influence to develop and extended trust model for information systems. Database for Advances in Information Systems, 37(2-3), 108-124.

Liang, H., Saraf, N., Hu, Q., \& Xue, Y. (2007). Assimilation of enterprise systems: The effect of institutional pressures and the mediating role of top management. MIS Quarterly, 31(1), 59-87.

Liao, C., Palvia, P., \& Chen, j.-L. (2009). Information technology adoption behavior life cycle: Toward a Technology Continuance Theory (TCT). International Journal of Information Management, 29, 309320.

Lucas, H. C. (1975). Performance and the use of an information system. Management Science, 21(8), 908919.

Malhotra, N. K., Kim, S. S., \& Patil, A. (2006). Common method variance in IS research: A comparison of alternative approaches and a reanalysis of past research. Management Science, 52(12), 1865-1883.

Markus, M. L. (1983). Power, politics, and MIS implementation. Communications of the ACM, 26(6), 430444.

Mathieson, K. (1991). Predicting user intentions: Comparing the technology acceptance model with the theory of planned behavior. Information Systems Research, 2(3), 173-191.

Nah, F. F.-H., Tan, X., \& Teh, S. H. (2004). An empirical investigation on end-users' acceptance of enterprise systems. Information Resources Management Journal, 17(3), 32-53.

Podsakoff, P. M., MacKenzie, S. B., Lee, J.-Y., \& Podsakoff, N. P. (2003). Common method biases in behavioral research: A critical review of the literature and recommended remedies. Journal of Applied Psychology, 88(5), 879-903.

Porter, C. E., \& Donthu, N. (2006). Using the technology acceptance model to explain how attitudes determine Internet usage: The role of perceived access barriers and demographics. Journal of Business Research, 59, 999-1007. 
Prybutok, V. R., \& Spink, A. (1999). Transformation of a health care information system: A selfassessment survey. IEEE Transaction on Engineering Management, 46(3), 299-310.

Rawstorne, P., Jayasuriya, R., \& Caputi, P. (1998). An integrative model of information systems use in mandatory environments. International Conference on Information Systems (pp. 325-330). Brisbane, Australia.

Rivard, S., \& Huff, S. L. (1988). Factors of success for end-user computing. Communications of the ACM, $31(5), 552-561$.

Robey, D. (1979). User attitudes and management information system use. Academy of Management Journal, 22(3), 527-538.

Salmela, H. (1997). From information systems quality to sustainable business quality. Information and Software Technology, 39, 819-825.

Schepers, J., \& Wetzels, M. (2007). A meta-analysis of the technology acceptance model: Investigating subjective norm and moderation effects. Information \& Management, 44, 90-103.

Shannon, C. E., \& Weaver, W. (1949). The mathematical theory of communication. Urbana, IL: The University of Illinois Press.

Taylor, S., \& Todd, P. A. (1995). Understanding information technology usage: A test of competing models. Information Systems Research, 6(2), 144-176.

Van der Heijden, H. (2004). User acceptance of hedonic information systems. MIS Quarterly, 28(4), 695704.

Venkatesh, V. (2000). Determinants of perceived ease of use: Integrating perceived behavioral control, computer anxiety and enjoyment into the technology acceptance model. Information Systems Research, 11(4), 342-365.

Venkatesh, V., \& Bala, H. (2008). Technology Acceptance Model 3 and a research agenda on interventions. Decision Sciences, 39(2), 273-315.

Venkatesh, V., \& Davis, F. D. (2000). A theoretical extension of the technology acceptance model: Four longitudinal field studies. Management Science, 46(2), 186-204.

Venkatesh, V., Morris, M. G., Davis, G. B., \& Davis, F. D. (2003). User acceptance of information technology: Toward a unified view. MIS Quarterly, 27(3), 425-478.

Wixom, B. H., \& Todd, P. A. (2005). A theoretical integration of user satisfaction and technology acceptance. Information Systems Research, 16(1), 85-102.

Yousafzai, S. Y., Foxall, G. R., \& Pallister, J. G. (2007a). Technology acceptance: A meta-analysis of the TAM: Part 1. Journal of Modelling in Management, 2(3), 251-280.

Yousafzai, S. Y., Foxall, G. R., \& Pallister, J. G. (2007b). Technology acceptance: A meta-analysis of the TAM: Part 2. Journal of Modelling in Management, 2(3), 281-304. 
Koh, Prybutok, Ryan, \& Wu

\section{Appendices}

\section{Appendix A. Scales of Constructs}

\section{Information Quality}

IQ1. Overall, I would give the information from the application high marks.

IQ2. Overall, I would give the information provided by the application high ratings in terms of quality.

IQ3. In general, the application provides me with high-quality information.

\section{Information Satisfaction}

IS1. Overall, the information I get from the application is very satisfying.

IS2. I am very satisfied with the information I receive from the application.

\section{Performance Expectancy}

PE1. I find the application useful to accomplish tasks.

PE2. Using the application enables me to accomplish tasks more quickly.

PE3. Using the application increases my productivity.

PE4. Using the application improves my job performance.

\section{Social Influence}

SI1. People who influence my behavioral think that I should use the application.

SI2. People who are important to me think that I should use the application.

\section{Attitude}

AT1. Using the application is a good idea.

AT2. The application makes work more interesting.

AT3. Working with the application is fun.

AT4. I like working with the application.

\section{Intention}

IN1. I intend to use the system in the next 12 months.

IN2. I predict I would use the system in the next 12 months.

IN3. I plan to use the system in the next 12 months.

\section{Use}

US1. How much time do you spend with the system during the ordinary day when you use computers? $\square$ Scarcely at all $\square$ Less than $1 / 2$ hour $\square 1 / 2-1$ hour $\square$ 1-2 hours $\square$ 2-3 hours $\square$ More than 3 hours

US2. How often on average do you use the system? $\square$ Less than once a month $\square$ Once a month $\square$ A few times a month $\square$ A few times a week $\square$ Once a day $\square$ Several times a day

\section{Overall Satisfaction}

OS1. I am pleased with my use of the application.

OS2. I am content with my use of the application.

OS3. I am satisfied with my use of the application.

OS4. I am delighted with my use of the application.

\section{Net Benefits}

NB1. The application provides competitive business advantage.

NB2. The application provides improved client relationship.

NB3. Overall the application is cost effective.

NB4. The application provides improved corporate image.

NB5. The application provides improved customer service.

NB6. The application keeps up with the organization's business requirements. 


\section{Appendix B. Applications Investigated in the Study}

\begin{tabular}{|c|c|c|c|c|c|c|c|c|}
\hline Application & Description & Functions and Objectives & Purpose & Users & Source & Platform & $\begin{array}{l}\text { Years } \\
\text { in use }\end{array}$ & $\begin{array}{c}\text { Owner } \\
\text { Department }\end{array}$ \\
\hline ArcView & $\begin{array}{l}\text { Desktop GIS } \\
\text { mapping } \\
\text { software }\end{array}$ & $\begin{array}{l}\text { Provides geographic data visualiza- } \\
\text { tion, mapping, management, \& } \\
\text { analysis capabilities along with the } \\
\text { ability to create \& edit data }\end{array}$ & Specific & 30 & OTC & Windows & 8 & Planning \\
\hline AutoCad & $\begin{array}{l}\text { Computer- } \\
\text { aided design } \\
\text { tool }\end{array}$ & $\begin{array}{l}\text { Produces design documents for } \\
\text { construction of city infrastructure } \\
\text { (water lines, streets, etc) }\end{array}$ & Specific & 20 & OTC & Windows & 12 & $\begin{array}{l}\text { Water Engi- } \\
\text { neering }\end{array}$ \\
\hline $\begin{array}{l}\text { BRIO } \\
\text { Report } \\
\text { Writing } \\
\text { Tool }\end{array}$ & $\begin{array}{l}\text { Report } \\
\text { writing tool }\end{array}$ & $\begin{array}{l}\text { Creates customized reports for Utility } \\
\text { Billing, Utility Finance, Fire, Police, } \\
\text { Tax. }\end{array}$ & General & 40 & Custom & Windows & 7 & $\begin{array}{l}\text { Technology } \\
\text { Services }\end{array}$ \\
\hline Cartegraph & $\begin{array}{l}\text { Asset man- } \\
\text { agement \& } \\
\text { work order } \\
\text { tracking } \\
\text { application }\end{array}$ & $\begin{array}{l}\text { Manages street, drainage, traffic, \& } \\
\text { sign assets }\end{array}$ & Specific & 15 & OTC & Windows & 6 & $\begin{array}{l}\text { Water Engi- } \\
\text { neering }\end{array}$ \\
\hline CityWorks & $\begin{array}{l}\text { Asset Man- } \\
\text { agement \& } \\
\text { work order } \\
\text { tracking } \\
\text { application }\end{array}$ & $\begin{array}{l}\text { Manages water lines, waste water } \\
\text { lines, fire hydrants \& water meters }\end{array}$ & Specific & 5 & OTC & Windows & 8 & $\begin{array}{l}\text { Water Field } \\
\text { Services }\end{array}$ \\
\hline Class & $\begin{array}{l}\text { Parks \& Rec } \\
\text { software } \\
\text { package for } \\
\text { recreational } \\
\text { activities }\end{array}$ & $\begin{array}{l}\text { Handles registrations, payments, } \\
\text { scheduling \& citizen records for } \\
\text { Parks \& Recreation offerings }\end{array}$ & Specific & 40 & OTC & MS SQL & 6 & $\begin{array}{l}\text { Parks Leisure } \\
\text { Services }\end{array}$ \\
\hline $\begin{array}{l}\text { Court } \\
\text { Specialists }\end{array}$ & $\begin{array}{l}\text { Municipal } \\
\text { Court Soft- } \\
\text { ware System }\end{array}$ & $\begin{array}{l}\text { Tracks cases, payments, jury pools, } \\
\& \text { warrants for misdemeanor cases; } \\
\text { Collects revenue for Municipal Court } \\
\text { fines \& fees }\end{array}$ & Specific & 20 & OTC & Unix & 8 & $\begin{array}{l}\text { Municipal } \\
\text { Court }\end{array}$ \\
\hline $\begin{array}{l}\text { Cust Serv } \\
\text { Call Man- } \\
\text { ager Cen- } \\
\text { ter }\end{array}$ & $\begin{array}{l}\text { Intelligent } \\
\text { call dispatch } \\
\text { \& routing } \\
\text { software }\end{array}$ & $\begin{array}{l}\text { Provides intelligent call management } \\
\text { for Utility customers }\end{array}$ & Specific & 30 & Custom & Cisco & 2 & $\begin{array}{l}\text { Water Cus- } \\
\text { tomer Ser- } \\
\text { vice }\end{array}$ \\
\hline $\begin{array}{l}\text { Faster } \\
\text { (CCG } \\
\text { Fleet) }\end{array}$ & $\begin{array}{l}\text { Vehicle } \\
\text { management } \\
\text { \& mainte- } \\
\text { nance soft- } \\
\text { ware }\end{array}$ & $\begin{array}{l}\text { Performs work orders, asset track- } \\
\text { ing, depreciation \& scheduling for } \\
\text { fleet management }\end{array}$ & Specific & 5 & OTC & MS SQL & 7 & $\begin{array}{l}\text { Fleet De- } \\
\text { partment }\end{array}$ \\
\hline Groupwise & $\begin{array}{l}\text { City wide e- } \\
\text { mail applica- } \\
\text { tion }\end{array}$ & $\begin{array}{l}\text { Performs e-mail, groupware \& calen- } \\
\text { daring functions }\end{array}$ & General & 900 & OTC & Novell & 10 & $\begin{array}{l}\text { Technology } \\
\text { Services }\end{array}$ \\
\hline $\begin{array}{l}\text { Harris } \\
\text { Billing } \\
\text { System }\end{array}$ & $\begin{array}{l}\text { Utility Billing } \\
\text { System }\end{array}$ & $\begin{array}{l}\text { Processes meter reads, utility bill } \\
\text { generation for electric, water, waste } \\
\text { water, solid waste \& drainage, work } \\
\text { order management, customer ac- } \\
\text { count tracking, \& payment collection }\end{array}$ & Specific & 150 & OTC & Unix & 9 & $\begin{array}{l}\text { Water Cus- } \\
\text { tomer Ser- } \\
\text { vice }\end{array}$ \\
\hline Intranet & $\begin{array}{l}\text { Internal } \\
\text { employee } \\
\text { website. }\end{array}$ & $\begin{array}{l}\text { Provides web-based forms such as } \\
\text { the P-card \& travel authorization \& } \\
\text { telephone numbers. Provides me- } \\
\text { dium for communicating information } \\
\text { to employees }\end{array}$ & General & 900 & Custom & Windows & 5 & $\begin{array}{l}\text { Technology } \\
\text { Services }\end{array}$ \\
\hline
\end{tabular}




\begin{tabular}{|c|c|c|c|c|c|c|c|c|}
\hline Application & Description & Functions and Objectives & Purpose & Users & Source & Platform & $\begin{array}{l}\text { Years } \\
\text { in use }\end{array}$ & $\begin{array}{c}\text { Owner } \\
\text { Department }\end{array}$ \\
\hline $\begin{array}{l}\text { JDE Peo- } \\
\text { plesoft }\end{array}$ & $\begin{array}{l}\text { Financial \& } \\
\text { human } \\
\text { resource } \\
\text { software } \\
\text { application }\end{array}$ & $\begin{array}{l}\text { Manages financial, accounting, } \\
\text { budgeting, purchasing, inven- } \\
\text { tory/warehousing, payroll \& human } \\
\text { resources system }\end{array}$ & General & 400 & OTC & Unix & 5 & Accounting \\
\hline LaserFiche & $\begin{array}{l}\text { Document } \\
\text { managing \& } \\
\text { imaging } \\
\text { software }\end{array}$ & $\begin{array}{l}\text { Provides paperless archival \& search } \\
\text { capabilities for city documents }\end{array}$ & General & 40 & Custom & MS SQL & 4 & $\begin{array}{l}\text { Technology } \\
\text { Services }\end{array}$ \\
\hline $\begin{array}{l}\text { Millennium } \\
\text { (Triple I) }\end{array}$ & $\begin{array}{l}\text { Library } \\
\text { Software } \\
\text { Application }\end{array}$ & $\begin{array}{l}\text { Collection management, patron } \\
\text { account tracking \& resource schedul- } \\
\text { ing }\end{array}$ & Specific & 50 & OTC & Unix & 3 & Library \\
\hline $\begin{array}{l}\text { Paradigm } \\
\text { System }\end{array}$ & $\begin{array}{l}\text { Solid waste } \\
\text { work man- } \\
\text { agement } \\
\text { system }\end{array}$ & $\begin{array}{l}\text { Manages work orders, scheduling, \& } \\
\text { intelligent routing for Solid Waste }\end{array}$ & Specific & 15 & OTC & MS SQL & 3 & Solid Waste \\
\hline PrintSmith & $\begin{array}{l}\text { Print shop } \\
\text { management } \\
\text { software }\end{array}$ & $\begin{array}{l}\text { Performs work order, job estimation } \\
\text { \& scheduling for Reprographics }\end{array}$ & Specific & 5 & ОTC & Windows & 1 & $\begin{array}{l}\text { Repro- } \\
\text { graphics }\end{array}$ \\
\hline $\begin{array}{l}\text { TaxOffice } \\
2000\end{array}$ & $\begin{array}{l}\text { Property tax } \\
\text { account } \\
\text { management } \\
\text { software }\end{array}$ & $\begin{array}{l}\text { Performs collection, account man- } \\
\text { agement \& analysis for property } \\
\text { valuations }\end{array}$ & Specific & 10 & OTC & MS SQL & 5 & Tax \\
\hline $\begin{array}{l}\text { CRW } \\
\text { Trak-it }\end{array}$ & $\begin{array}{l}\text { Development } \\
\text { services } \\
\text { application }\end{array}$ & $\begin{array}{l}\text { Tracks development projects from } \\
\text { pre-design through construction, } \\
\text { inspection \& code compliance; } \\
\text { Maintains business licensing \& code } \\
\text { enforcement }\end{array}$ & General & 150 & OTC & MS SQL & 6 & Planning \\
\hline VisionAir & $\begin{array}{l}\text { Public safety } \\
\text { operations } \\
\text { management } \\
\text { software } \\
\text { suite }\end{array}$ & $\begin{array}{l}\text { Performs computer-aided dispatch, } \\
\text { records management, call tracking, } \\
\text { GPS unit tracking, mapping, routing } \\
\text { analysis, jail management \& TLETS } \\
\text { host integration }\end{array}$ & Specific & 150 & OTC & MS SQL & 4 & Police \\
\hline
\end{tabular}




\section{Appendix C. Number of Respondents by Department and Application}

\begin{tabular}{|c|c|c|c|c|c|c|c|c|c|c|c|c|c|c|c|c|c|c|c|c|c|c|}
\hline \multirow[b]{2}{*}{ Department } & \multicolumn{21}{|c|}{ Applications } & \\
\hline & 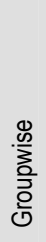 & 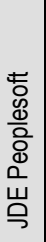 & 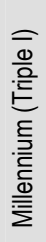 & 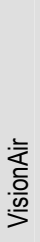 & 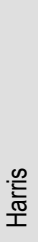 & 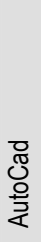 & 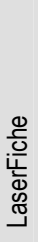 & 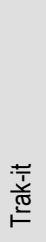 & $\frac{\sum_{0}^{3}}{\frac{0}{2}}$ & 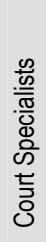 & 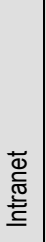 & $\begin{array}{l}\mathscr{W} \\
\frac{\pi}{0} \\
\end{array}$ & 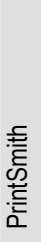 & $\begin{array}{l}\text { 토 } \\
\text { 흠 } \\
\frac{\pi}{\pi} \\
\square\end{array}$ & 음 & 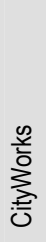 & 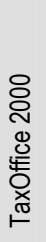 & 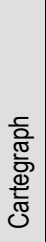 & 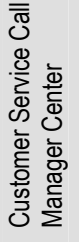 & 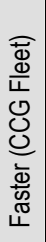 & 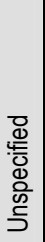 & 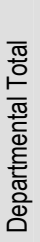 \\
\hline Public Safety & $\begin{array}{l}2 \\
8\end{array}$ & 1 & & $\begin{array}{l}2 \\
1\end{array}$ & & 1 & 1 & & & & 2 & & 1 & & 1 & & & & & & 4 & $\begin{array}{l}6 \\
0\end{array}$ \\
\hline $\begin{array}{l}\text { Water, Wastewater \& } \\
\text { Drainage }\end{array}$ & $\begin{array}{l}2 \\
2\end{array}$ & 4 & 1 & 1 & 2 & 2 & 1 & 3 & 2 & & 1 & & & & & 2 & & & & & & $\begin{array}{l}4 \\
1\end{array}$ \\
\hline $\begin{array}{l}\text { Budget \& Fiscal Op- } \\
\text { erations }\end{array}$ & 7 & $\begin{array}{l}2 \\
0\end{array}$ & & & & & 2 & & & & 1 & & & & & & 3 & & & & & $\begin{array}{l}3 \\
3\end{array}$ \\
\hline Library & 8 & 1 & $\begin{array}{l}2 \\
4\end{array}$ & & & & & & & & & & & & & & & & & & & $\begin{array}{l}3 \\
3\end{array}$ \\
\hline Electric & $\begin{array}{l}1 \\
1\end{array}$ & 2 & & & 5 & 3 & & & & & & & & & 1 & & & & & & 2 & $\begin{array}{l}2 \\
4\end{array}$ \\
\hline Technology Services & $\begin{array}{l}1 \\
3\end{array}$ & 1 & & & & & & & & & 1 & & & & 1 & & & & & & 2 & $\begin{array}{l}1 \\
8\end{array}$ \\
\hline Parks and KDB & 8 & & & & 1 & 1 & & & & & & 5 & & & & & & & & & & $\begin{array}{l}1 \\
5\end{array}$ \\
\hline $\begin{array}{l}\text { Solid Waste, Landfill \& } \\
\text { Recycling }\end{array}$ & 7 & & & & 1 & & & & 1 & & 1 & & 1 & 3 & & & & & & & & $\begin{array}{l}1 \\
4\end{array}$ \\
\hline Customer Service & & & & & $\begin{array}{l}1 \\
0\end{array}$ & & & & & & & & & 1 & & & & & 1 & & & $\begin{array}{l}1 \\
2\end{array}$ \\
\hline $\begin{array}{l}\text { Comm/Downtown/ } \\
\text { Econ. Dev. }\end{array}$ & 7 & 1 & & 1 & & 1 & 1 & & & & & & & & & & & & & & & $\begin{array}{l}1 \\
1\end{array}$ \\
\hline $\begin{array}{l}\text { Planning and Building } \\
\text { Inspection }\end{array}$ & 2 & & & & & & & 5 & 3 & & & & & & & & & & & & & $\begin{array}{l}1 \\
0\end{array}$ \\
\hline General Government & 6 & 1 & & & & & 1 & & & & & & 1 & & & & & & & & 1 & $\begin{array}{l}1 \\
0\end{array}$ \\
\hline Human Resources & 3 & 3 & & & & & 1 & & & & 1 & & 1 & & & & & & & & & 9 \\
\hline Facility Management & 5 & 1 & & & & & 1 & & & & & & & & & & & & & & & 7 \\
\hline Transportation & 4 & 1 & & & & & & & 1 & & & & & & & & & 1 & & & & 7 \\
\hline $\begin{array}{l}\text { Municipal Court and } \\
\text { Judge's Office }\end{array}$ & & & & & & & & & & 6 & & & & & & & & & & & & 6 \\
\hline Utilities Administration & 3 & & 1 & & & 1 & & & & & & & & & & 1 & & & & & & 6 \\
\hline Legal & 5 & & & & & & & & & & & & & & & & & & & & & 5 \\
\hline $\begin{array}{l}\text { Safety, Training, Risk } \\
\text { Management }\end{array}$ & 3 & & & & & & & & & 1 & & & & & & & & & & & & 4 \\
\hline $\begin{array}{l}\text { Motor Pool and Main- } \\
\text { tenance }\end{array}$ & & & & & & & & & & & & & & & & & & & & 1 & & 1 \\
\hline Other & 1 & & & & & 3 & 1 & & & & & & 1 & & & & & & & & 1 & 7 \\
\hline Application Total & $\begin{array}{l}1 \\
4 \\
3\end{array}$ & $\begin{array}{l}3 \\
6\end{array}$ & $\begin{array}{l}2 \\
6\end{array}$ & $\begin{array}{l}2 \\
3\end{array}$ & $\begin{array}{l}1 \\
9\end{array}$ & $\begin{array}{l}1 \\
2\end{array}$ & 9 & 8 & 7 & 7 & 7 & 5 & 5 & 4 & 3 & 3 & 3 & 1 & 1 & 1 & $\begin{array}{l}1 \\
0\end{array}$ & $\begin{array}{l}3 \\
3 \\
3\end{array}$ \\
\hline
\end{tabular}




\section{Biographies}

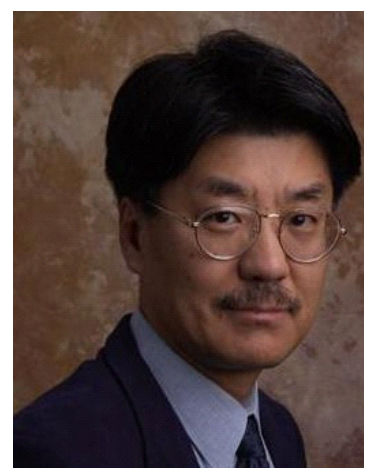

Chang E. Koh is Farrington Professor of Information Systems in the Information Technology and Decision Sciences Department at the University of North Texas. He also serves as Managing Director for the Center for Decision and Information Technologies at UNT. His major research interests include business implementation of Radio Frequency ID (RFID) technology, business Internet practices and strategies, egovernment readiness and barriers, and international/cross-cultural issues of IT implementation. His research articles have appeared in such journals as MIS Quarterly, Information \& Management, Industrial Marketing Management and International Journal of Electronic Commerce among others. He holds a Ph.D. from the University of Georgia in Information Systems.

Victor R. Prybutok is a Regents Professor of Decision Sciences in the Information Technology

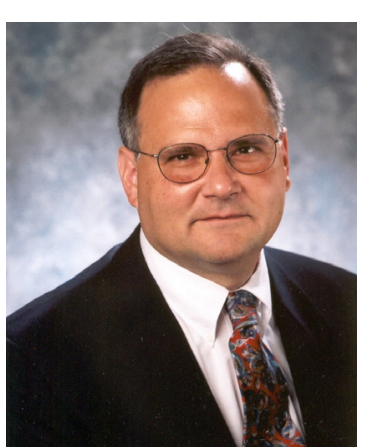
and Decision Sciences Department and Interim Associate Dean of the Toulouse School of Graduate Studies at the University of North Texas. He received, from Drexel University, his B.S. with High Honors in 1974, a M.S. in Bio-Mathematics in 1976, a M.S. in Environmental Health in 1980, and a Ph.D. in Environmental Analysis and Applied Statistics in 1984. Dr. Prybutok is an ASQ certified quality engineer, certified quality auditor, certified manager of quality / organizational excellence, and served as a Texas Quality Award Examiner in 1993. Dr. Prybutok has authored over 100 journal articles, several book chapters, and more than 70 conference presentations in information systems measurement, quality control, risk assessment, and applied statistics.

Sherry D. Ryan is an Associate Professor of Information Technology and Decision Sciences at

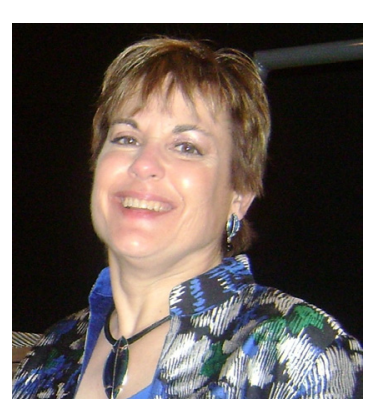
the University of North Texas. She received her Ph.D. in IS from the University of Texas at Arlington and an MBA from the University of Southern California. Prior to returning to academia she worked for IBM, teaching courses and speaking at national conferences. Her research interests include social networks, IT human resource issues, and virtual teams and communities. Her work has appeared in journals including Journal of Management Information Systems, Informing Science: The International Journal of an Emerging Transdiscipline, Decision Support Systems, Information and Management, and DATA BASE.

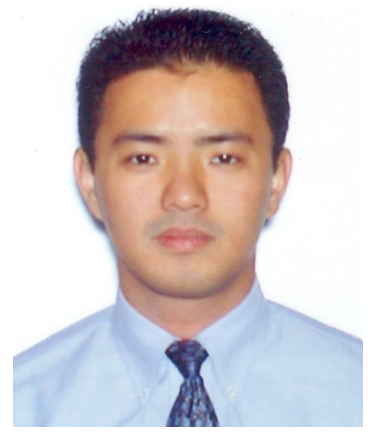

Yu "Andy" Wu is an assistant professor in the Department of Information Technology and Decision Sciences, College of Business at the University of North Texas. He received a Ph.D. in Management Information Systems from the University of Central Florida, Orlando, FL, in 2007. His primary research interests include social networks and information security. His research papers appeared in international conferences and journals including Informing Science, Journal of Organizational and End User Computing, International Journal of Networking and Virtual Organizations, etc. Before his academic career, Dr. Wu had seven years' experiences in various business and management positions. 